Review article

\title{
Red ferruginous soils of tropical Indian environments: A review of the pedogenic processes and its implications for edaphology
}

\author{
D.K. Pal ${ }^{\text {a,* }}$, S.P. Wani ${ }^{\text {a }}$, K.L. Sahrawat ${ }^{\text {a }}$, P. Srivastava ${ }^{b}$ \\ ${ }^{a}$ Resilient Dry Land Systems, International Crops Research Institute for the Semi-Arid Tropics (ICRISAT), Patancheru 502 324, Andhra Pradesh, India \\ ${ }^{\mathrm{b}}$ Department of Geology, University of Delhi, Delhi 110007, India
}

\section{A R T I C L E I N F O}

\section{Article history:}

Received 12 December 2013

Received in revised form 7 March 2014

Accepted 26 May 2014

Available online 17 June 2014

\section{Keywords:}

Tropical soils

Alfisols

Mollisols

Ultisols

Pedology

Edaphology

\begin{abstract}
A B S T R A C T
Red ferruginous (RF) soils of tropical Indian environments belong to Entisols, Inceptisols, Alfisols, Mollisols and Ultisols soil orders. The occurrence of Ultisols alongside acidic Alfisols and Mollisols in both zeolitic and nonzeolitic parent materials in humid tropical (HT) climatic environments, indicates that the soil diversity in India is large. These soils are not confined to a single production system and generally maintain a positive organic carbon (OC) balance without adding significantly to greenhouse gas emissions. This review presents a synthesis of literature on the recent developments on the pedology of RF soils, including their physical, chemical, biological, mineralogical and micro-morphological properties, and their degradation status. It also addresses the changes in soil properties in semi-arid tropical (SAT) areas, created by climate shift during the Holocene. This knowledge contributed to our understanding as to how the parent material composition influences the formation of Alfisols, Mollisols and Ultisols in weathering environments of HT climate; and also as to how the relict Alfisols of SAT areas are polygenetic. The state-of-the-art information developed through the extensive work on such soils has helped establish an organic link between pedogenetic processes and bulk soil properties, and has provided an insight of many pedological and edaphological issues related to Alfisols, Mollisols and Ultisols mainly of HT climate. The synthesis has helped us to understand as to why the formation of Oxisols from Ultisols is an improbable genetic pathway in tropical environment of India and elsewhere in the world. There is a strong need to modify the mineralogy class of highly weathered RF soils. We hope this review will help to dispel some of the myths on the formation of tropical soils and their low fertility by putting in context their characteristics and capacity to be productive.
\end{abstract}

(c) 2014 Elsevier B.V. All rights reserved.

\section{Contents}

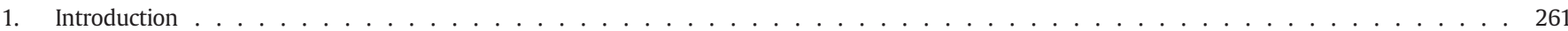

2. Taxonomic classes and factors in the formation of RF soils . . . . . . . . . . . . . . . . . . . . . . . . . . . . . . . . 261

3. Clay enriched B horizons, clay illuviation and taxonomic rationale of RF soils of HT climate . . . . . . . . . . . . . . . . . . . . . . . . . . . . 261

4. RF soils (Alfisols) in semi-arid tropics (SAT) - evidence of climate change and polypedogenesis . . . . . . . . . . . . . . . . . . . . . . . . 263

5. Acidity and its nature and charge characteristics in RF soils of HT climate . . . . . . . . . . . . . . . . . . . . . . . . . . . . . . . . . . 266

6. Mineralogy of RF soils of the HT climate . . . . . . . . . . . . . . . . . . . . . . . . . . . . . . . . . . . . . 269

6.1. Genesis of kaolinite and gibbsite . . . . . . . . . . . . . . . . . . . . . . . . . . . . . . . . . . . . . . 269

6.2. Rationale for mineralogy class for RF soils of HT climate . . . . . . . . . . . . . . . . . . . . . . . . . . . . . . . . . . 270

7. Ultisols of humid tropical climate of India in context with global Oxisols . . . . . . . . . . . . . . . . . . . . . . . . . . . 270

8. Modelling RF soils developed in HT climate of India . . . . . . . . . . . . . . . . . . . . . . . . . . . . . . . . . . . . . . . . . . 271

9. Importance of pedology of RF soils in their edaphology . . . . . . . . . . . . . . . . . . . . . . . . . . . . . . . . . . . . . . . . . 271

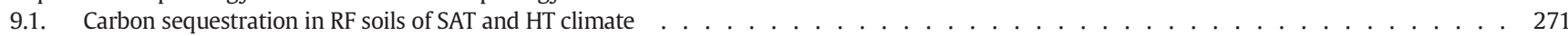

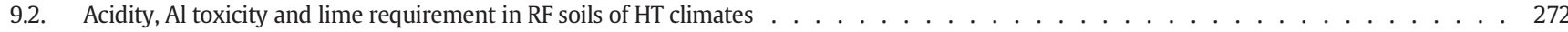

9.3. Nature of minerals in the adsorption and desorption of major nutrients in RF soils of the humid and SAT environments . . . . . . . . . 272

9.3.1. Nitrogen . . . . . . . . . . . . . . . . . . . . . . . . . . . . . . . . . . . . . . 272

9.3.2. Phosphorus ............................................. 273

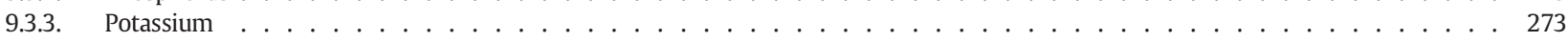

\footnotetext{
* Corresponding author. Fax: +9140307 13074.

E-mail addresses: paldilip2001@yahoo.com (D.K. Pal), s.wani@cgiar.org (S.P. Wani), k.sahrawat@cgiar.org (K.L. Sahrawat), pankajps@gmail.com (P. Srivastava).
} 


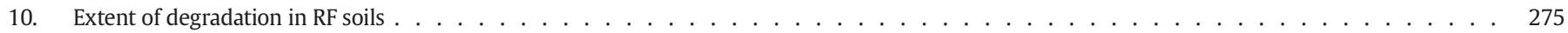

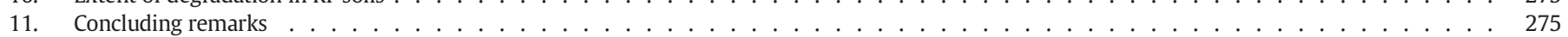

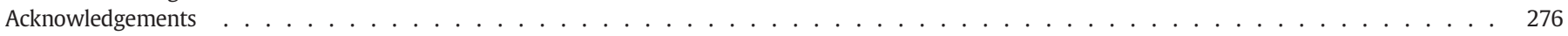

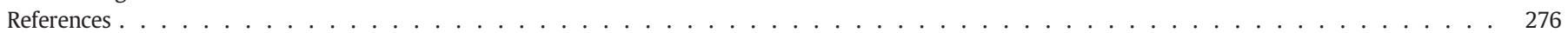

\section{1 . Introduction}

Major part of the land area in India is in the region lying between the Tropic of Cancer and Tropic of Capricorn, where the soils are classed "tropical". In the Indian sub-continent tropical soils include group of soils variously termed 'red', 'brown', 'yellow', 'laterite', 'lateritic', 'ferralitic' and 'latosols'. As these soils lack precise definition, and they are termed as red ferruginous soils (Pal et al., 2000a; Rengasamy et al., 1978), which denote that they are rubefied soils (7.5 YR to 2.5 YR hue) of tropical India characterized by reddish colour, stable structure mainly by the influence of iron oxides, poor base status, and highly to moderately acidic in reaction (Pal et al., 2000a). These soils mostly occur in the semi-arid to humid tropical and sub-tropical regions in eight agro-ecological regions of India. They cover one-fourth of the total geographical area of 329 millon ha and are found in the states/ union territories of Kerala, Tamil Nadu, Karnataka, Andhra Pradesh, Madhya Pradesh, Gujarat, Maharashtra, Goa, Orissa, Bihar, West Bengal, Sikkim, Manipur, Nagaland, Mizoram, Meghalaya, Arunachal Pradesh, Assam, Tripura, Pondicherry and Andaman and Nicobar islands (Bhattacharyya et al., 2009; Sehgal, 1998). As the tropics comprise approximately $40 \%$ of the land surface of the earth, more than one-third of the soils of the world are tropical soils (Eswaran et al., 1992a). Global distribution and research on these soils indicate that some of the agricultural management practices developed in one part of the tropical world for enhancing crop productivity and maintaining soil health, for example, through $C$ sequestration and other management interventions, might also be applicable to similar soils elsewhere.

The Indian tropical soils are not confined to a single production system. Current information on their agricultural land uses (edaphology) demonstrates that they capture a wide variability in use for cereal production in the semi-arid, sub-humid, per-humid and coastal climatic environments. These soils also support forestry, horticultural, spices and cash crops. They thus contribute substantially to India's growing self-sufficiency in food production and food stocks. In general, the management of the Indian tropical red ferruginous soils is site-specific and requires an understanding of the degradation and regeneration processes to optimize their use by developing appropriate management practices (Sehgal, 1998). Basic pedological research is needed to understand some of the basic unresolved edaphological aspects of these soils to develop improved management practices. Thus, a critical review of the Indian tropical RF soils and their pedogenetic processes that are linked to selected soil bulk properties is in order.

A basic inventory on the occurrence of RF soils in Indian tropical environments is available with benchmark status for many of these soils (Lal et al., 1994; Murthy et al., 1982) courtesy by the National Bureau of Soil Survey and Land Use Planning (NBSS\&LUP, ICAR), Nagpur, India (Bhattacharyya et al., 2009). Over the past two decades however, the focus of research has shifted from general pedology to mineralogical and micro-morphological and climate change research. Although this review is based on study of selected benchmark Indian tropical RF soils, data from other tropical parts of the world are also included where relevant.

This review addresses the changes in soil properties as a result of climatic shift during the Holocene. Such changes in soil properties more importantly a general trend in their degradation are especially exacerbated with a rise in mean annual temperature (MAT) and decrease in mean annual rainfall (MAR). Indeed, climate change effects on soils in the semi-arid tropical (SAT) regions are observed in their chemical degradation as a result of increased formation of pedogenic
$\mathrm{CaCO}_{3}$ and concomitant increase in subsoil sodicity. This regressive pedogenic processes observed in vast areas of SAT red ferruginous soils (Table 1) manifests as decreased crop productivity under rain fed agricultural systems. This general degradation of soil resource needs urgent attention for developing management strategies to rejuvenate the degraded soil resource base as the livelihoods of a large number of small and poor farmers depends on these soils (Pal et al., 2013). The main objective of this review is to integrate the available information on the pedology and edaphology of RF soils to optimize their use for food security in India and other tropical regions in the 21st century.

\section{Taxonomic classes and factors in the formation of RF soils}

The RF soils are mostly developed on granite, granite-gneiss, ferruginous sandstone and schist of Achaean Period, and in places on Deccan basalt, shale, limestone and in marine deposits (Bhattacharyya et al., 2009; Sehgal, 1998) (Table 1). They have thermic, isothermic, hyperthermic and isohyperthermic soil temperature regimes, and their soil moisture regimes are ustic, udic and aquic. Although the soils belong to Entisols, Inceptisols, Alfisols, Ultisols and Mollisols orders of the US Soil Taxonomy (Bhattacharyya et al., 2009), their soil orders are not similar under all soil moisture and temperature regimes. Under humid tropical (HT) climates, they are Inceptisols, Alfisols, Mollisols, and Ultisols in Kerala; Inceptisols, Alfisols, and Ultisols in Goa; Alfisols, Mollisols, and Ultisols in Karnataka; Alfisols, Mollisols, and Ultisols in Tamil Nadu; Inceptisols, Alfisols and Mollisols in Maharashtra; Alfisols in Gujarat; Entisols and Inceptisols in Sikkim; Entisols, Inceptisols, Alfisols and Ultisols in Arunachal Pradesh; Entisols, Inceptisols, Alfisols and Ultisols in Assam; Inceptisols, Alfisols and Ultisols in Manipur; Entisols, Inceptisols, Alfisols and Ultisols in Mizoram; Entisols, Inceptisols, Alfisols and Ultisols in Meghalaya; Entisols, Inceptisols, Alfisols and Ultisols in Nagaland; Inceptisols, Alfisols and Ultisols in Tripura; and Alfisols and Mollisols in Andaman and Nicobar Islands (Table 1).

In arid, semi-arid and sub-humid climates, RF soils also belong to different soil orders. Under these relatively dry climates they are Entisols, Inceptisols, Alfisols and Mollisols in Andhra Pradesh; Inceptisols and Alfisols in Karnataka; Inceptisols and Alfisols in Tamil Nadu; Entisols, Inceptisols and Alfisols in Bihar; Entisols and Alfisols in Orissa; Alfisols and Mollisols in Madhya Pradesh; Alfisols in West Bengal; and Alfisols in Puducherry (Table 1). Taxonomic diversity in RF soils of India thus suggests that soil diversity in the geographic tropics of India is as large as that observed in the temperate regions (Eswaran et al., 1992a; Sanchez, 1976; Sanchez and Logan, 1992). From this it follows that generalizations on the management of RF soils would be rather hazardous as they are unlikely to have wider applicability because of a large diversity in these soils as a result of their genesis leading to a wide range in physical, chemical and biological properties. In the following sections, we deal with the diversity of RF soils caused by parent material composition, the presence of soil modifiers, climate and vegetation.

\section{Clay enriched B horizons, clay illuviation and taxonomic rationale of RF soils of HT climate}

Except for the Entisols and Inceptisols, Ultisols, Alfisols and Mollisols have clay enriched B horizons. Texture in these soils varies from fine loamy to clayey (Bhattacharyya et al., 2009); and the soils are in general mild to strongly acidic. Despite the acidity, Alfisols and Mollisols maintain the required base saturation, because of the enrichment by basic 
Table 1

Distribution of RF soils in agro-ecological regions, major physiography, parent material and Indian states and their taxonomic soil orders.

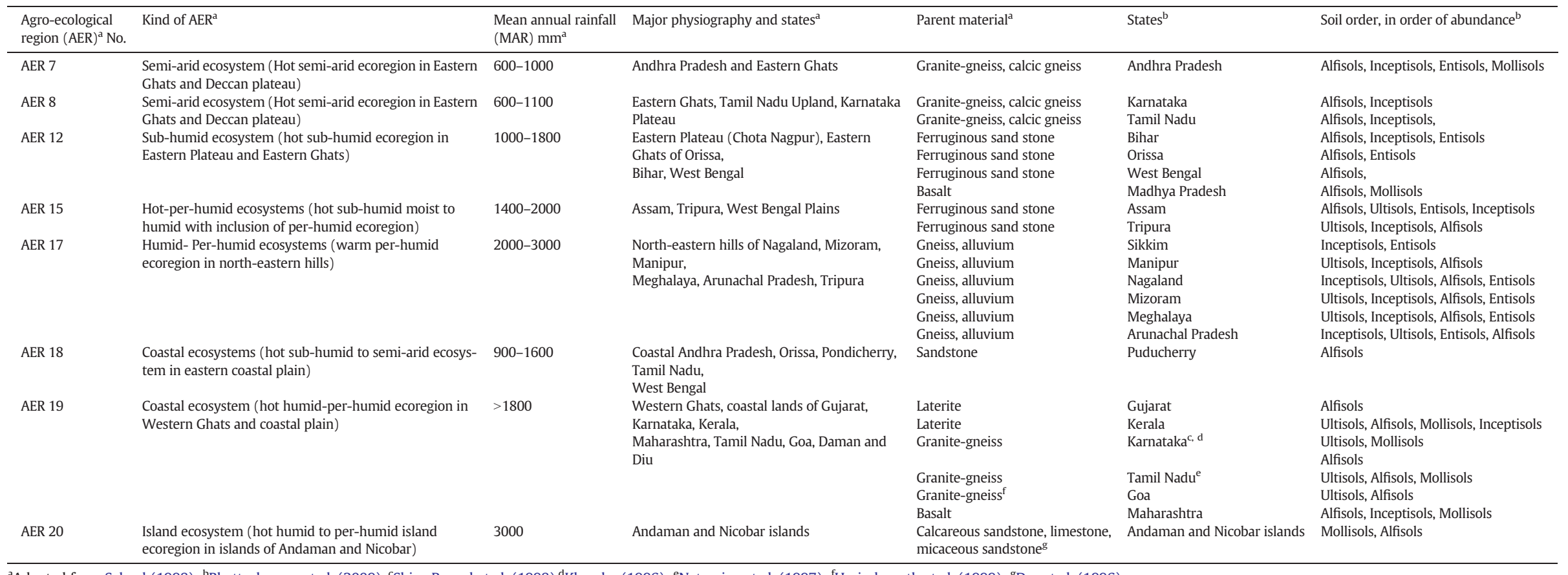

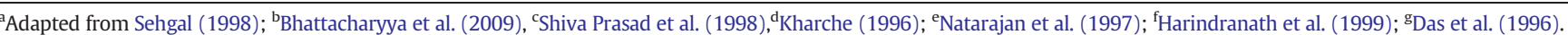


cations of the parent material derived from calc-gneiss rock (Harindranath et al., 1999; Krishnan et al., 1996; Natarajan et al., 1997; Shiva Prasad et al., 1998) and limestone (Das et al., 1996). Identification of the argillic horizon in Indian Ultisols has been always difficult in the field (Bhattacharyya et al., 1994; Sen et al., 1994) and elsewhere (Beinroth, 1982; Eswaran, 1972; Rebertus and Buol, 1985). This has caused confusion on their appropriate place in the US Soil Taxonomy.

The introduction of 'Kandic' concept in Soil Taxonomy (Survey Staff, 1990) however, provides a scope to eliminate the requirement for argillic horizon in Ultisols, which are generally low activity clay (LAC) soils. Many Ultisols of Kerala (Eswaran et al., 1992b; Krishnan et al., 1996), Tamil Nadu (Natarajan et al., 1997), Karnataka (Eswaran et al., 1992b; Kharche, 1996; Shiva Prasad et al., 1998) in the southern peninsular area and of Arunachal Pradesh, Assam, Meghalaya, Nagaland, Tripura (Sen et al., 1997a) and Manipur (Sen et al., 1994) in the northeastern hills (NEH) have sub-surface horizons that meet the textural and depth requirement of the Kandic horizon.

Surface soils are strong to moderately acidic and the sub-surface soils are very strongly acidic resulting in poor base status. Soils have $>0.9 \%$ organic carbon (OC), which decreases with depth. The CEC (by $1 \mathrm{~N} \mathrm{NH}_{4} \mathrm{OAc}, \mathrm{pH} 7$ ) and ECEC (sum of bases extracted with $1 \mathrm{~N}$ $\mathrm{NH}_{4} \mathrm{OAc}$, pH 7 plus $1 \mathrm{~N} \mathrm{KCL}$ extractable $\mathrm{Al}^{3+}$ ) of clay in the subsurface horizons are less than $16 \mathrm{cmol}\left(\mathrm{p}^{+}\right) \mathrm{kg}^{-1}$ even with high OC and clay content. Thus, such soils qualify for LAC soils and lend support to the existence of Kandic horizon. However, many non-LAC soils of NEH have no lithological discontinuity but have requisite clay enrichment in the argillic horizon without identifiable clay skins in the field (Sen et al., 1997b). Similar observations have also been made earlier for the semi-arid soils of the Indo-Gangetic Alluvial Plains (IGP), and a detailed micro-morphological study (Pal et al., 1994) confirmed the occurrence of clay illuviation process in these soils. In the absence of confirmation of clay illuviation process by thin-section studies, such acid soils of NEH with clay enriched B horizons have hitherto been placed under Dystrochrepts (Sen et al., 1997b). But these authors strongly felt that such classification undermines a major pedogenic process operating in these soils.

To investigate the precise cause-effect relation of the presence/ absence of clay skins (that are generally identified by $10 \times$ hand lens in the field) a detailed micro-morphological study of acidic $\mathrm{pH}$ soils of India is therefore warranted. Limited data on the clay pedofeatures in such soils (particularly Ultisols and soils with Ultic characters) in India (Kooistra, 1982) and elsewhere (Eswaran and Sys, 1979) indicate the presence of pure void argillans (Fig. 1a). But such clay pedofeatures are not considered to be the result of current pedogenic processes (Eswaran and Sys, 1979; Kooistra, 1982). The dispersion of clay particles is possible under slightly acidic to moderately alkaline $\mathrm{pH}$ conditions at a very low electrolyte concentration that ensures a $\mathrm{pH}$ higher than that required for the zero point of charge for complete dispersion of clay (Eswaran and Sys, 1979). Therefore, the movement of deflocculated clays (and its subsequent accumulation in the Bt horizons) occurs at the initial stage of soil formation when the $\mathrm{pH}$ is moderately alkaline and remains above the point of zero charge. Such chemical environment would result in deflocculation, disengaging face-to-face association of clay particles (Van Olphen, 1966); and consequently likely cause impairment of parallel orientation of the clay platelets. In this colloidal state, the translocation of the fine clay particles would result in textural pedofeatures of the 'impure type' (Fig. 1b) as observed in soils of the north-western (NW) parts of the IGP during the Holocene (Pal et al., 1994).

The presence of pure void argillans reported in some RF soils suggests that with the advancement in weathering and leaching of bases, and concomitant lowering of $\mathrm{pH}$ during the initial stages of pedogenesis in HT climate, clay platelets could remain in face to face association or parallel, or oriented aggregation when the flocculation of the clay suspension was not induced by the presence of salts (Van Olphen, 1966), particularly the carbonates and bicarbonates of sodium (Pal et al., 1994). Therefore, the clay illuviation in such highly weathered acidic soils of HT climate is not a current pedogenetic process and thus justifies the contention by Eswaran and Sys (1979) and Kooistra (1982). This is further supported by the presence of granular microstructure, organic matter rich flocculated clay granules, and thin-to-thick ferruginous clay coatings in these soils as observed by Kooistra (1982). A recent synthesis of information on clay enriched horizons also suggests similar illuvial features in ferruginous soils (Bockheim and Hartemink, 2013).

\section{RF soils (Alfisols) in semi-arid tropics (SAT) - evidence of climate change and polypedogenesis}

In parts of southern and eastern India, laterite mounds and laterite plateau remnants are scattered over the landscape (Pal and Roy, 1978; Rengasamy et al., 1978; Subramanian and Mani, 1981). In central and western India thin-to-thick $(25-300 \mathrm{~cm})$ laterite cappings occur on various rock types ranging in ages from Archean to Gondwanas (Pascoe, 1965; Sahasrabudhe and Deshmukh, 1981; Subramanian and Mani, 1981). Large numbers of massive granitic tors in gneissic terrain bear the evidence of exhumation (Pal and Deshpande, 1986; Pal and Deshpande, 1987) during the dry period following prolonged deep weathering in the HT climate that prevailed from the Upper Cretaceous (Subramanian and Mani, 1981) until Plio-Pleistocene. The Plio-Pleistocene was a transition period when the climate became drier with rising of the Western Ghats (Brunner, 1970). As a result, the upper layers of RF soils (mainly Paleustalfs and Rhodustalfs, Natarajan et al., 1997; Shiva Prasad et al., 1998) formed in the preceding (a)

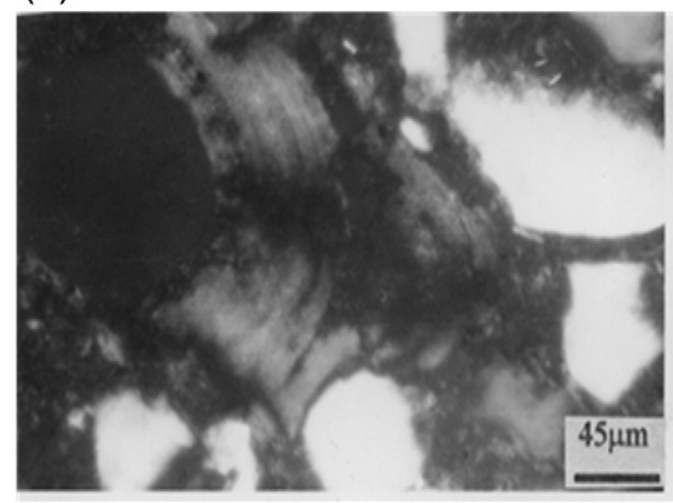

(b)

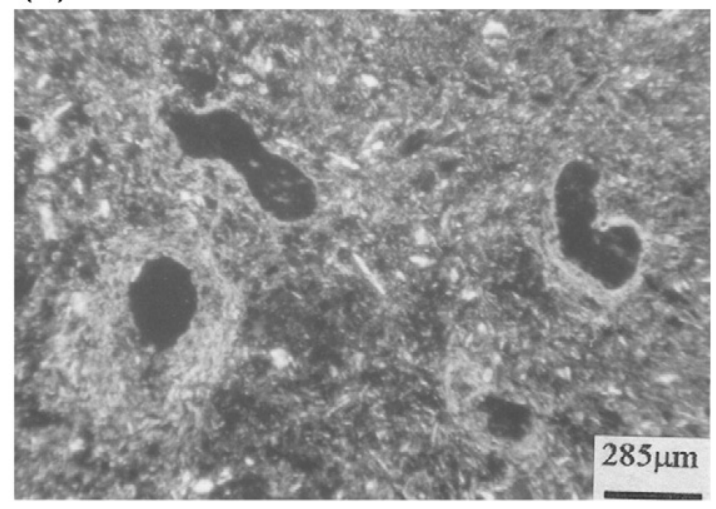

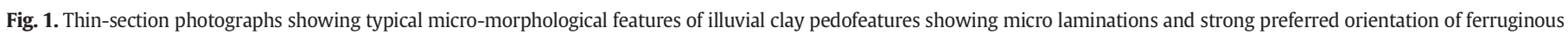
soils of southern India (a) (Adapted from Venugopal et al., 1991), and impure clay pedofeatures in soils of the NW part of the IGP (b) (adapted from Pal et al., 2003). 
HT climate, were truncated by multiple arid erosional cycles (Chandran et al., 2000; Murali et al., 1978; Rengasamy et al., 1978). Due to probable truncation of the upper layers, the coarse and fine clay contents presently show an upward increase in the solum, a sharp decline in the Ap horizon (Fig. 2a) and argillans immediately beneath the Ap horizon (Chandran et al., 2000; Murthy et al., 1982; Pal et al., 1989). Such modification in the geomorphic surface is also evident from the presence of broken argillans (papules) (Kooistra, 1982; Venugopal, 1997; Venugopal et al., 1991) in the soil solum, which possibly represent low-energy short distance transport in the upland undulating areas (Srivastava et al., 2010).

Most of the SAT Alfisols have fine loamy to clayey texture (Bhattacharyya et al., 2009), and are in general calcareous and almost neutral to mildly alkaline in nature. These Alfisols are spatially associated with Vertisols (Typic/Aridic/Sodic Haplusterts, Pal et al., 2012a) and contain both dioctahedral smectite and kaolinite (Bhattacharyya et al., 1993, 1999) in their clay fractions alongside mica (Chandran et al., 2000; Pal et al., 1987, 1989). Such selected soils however, are dominated by kaolin with small amount of smectite (Pal et al., 1987). It was observed that kaolinite decreases and smectite increases with depth, and the sum of these two minerals are fairly constant from the B to the $C$ (saprolites) horizon (Fig. 2b). Such relation suggests the transformation of smectite to kaolinite, which generally occurs through an intermediate phase of smectite-kaolinite ( $\mathrm{Sm}-\mathrm{Kl}$ ) interstratifications identifiable by broad basal reflections of kaolinite at $0.74-0.75$ and $0.35 \mathrm{~nm}$ (Bhattacharyya et al., 1993; Herbillon et al., 1981; Yerima et al., 1985) (Fig. 3). However, in few bench mark SAT Alfisols of the Mysore plateau in Karnataka (Murthy et al., 1982), $0.7 \mathrm{~nm}$ mineral is a fairly well crystalline kaolinite mineral (XRD diagram shown in inset, Fig. 4b) as the weathered product of biotite (Fig. 5a), and is observed as hexagonal crystals under SEM as pseudomorphs after plagioclase (Fig. 5b). The calculated unit cell cation composition of such kaolinites showed a substitution of 0.11-0.82 atoms of Fe(III) for Al in every four octahedral sites (Rengasamy et al., 1975). Schwertmann and Herbillon (1992)
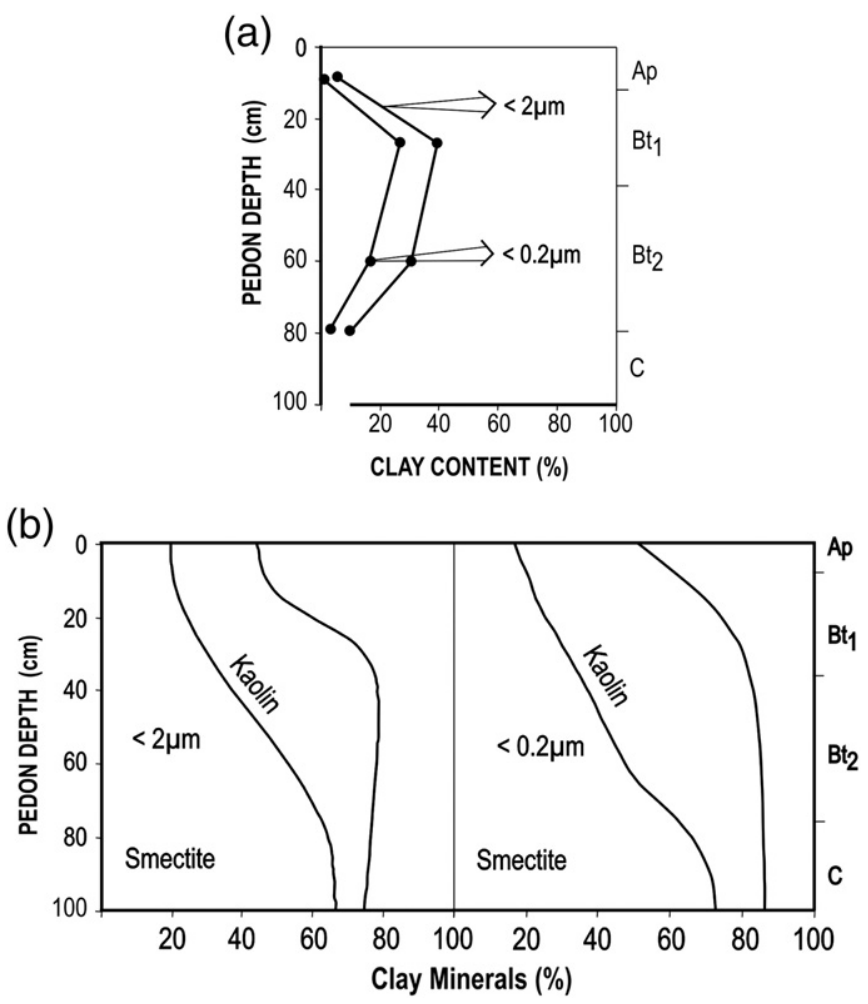

Fig. 2. Depth-wise distribution of clay fraction (a) and clay size smectite and kaolin (b) with pedon depth of a representative SAT Alfisol. Adapted from Pal et al. (2000a) and Pal et al. (1987).

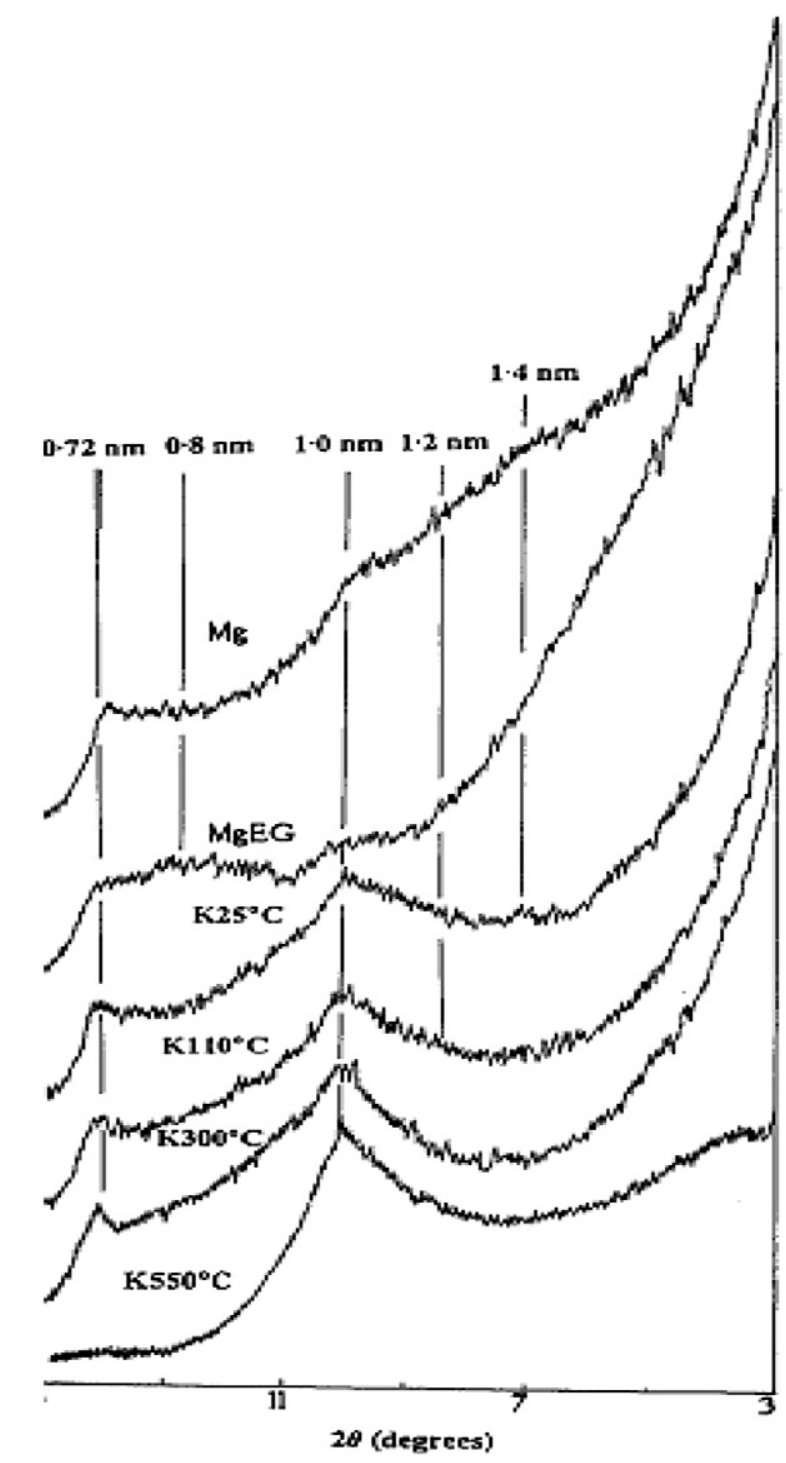

Fig. 3. X-ray diffractograms of the $0.72 \mathrm{~nm}$ and HIS minerals in the fine clays of the representative Alfisols developed on zeolitic Deccan basalts of HT climate. Adapted from Bhattacharyya et al. (1993).

suggested that such substitutions inhibit crystal development and thereby keep the kaolinite more active with higher surface area.

Ray et al. (2001) observed that kaolinites in Alfisols of Jharkhand have CEC more than $30 \mathrm{cmol}\left(\mathrm{p}^{+}\right) \mathrm{kg}^{-1}$. In such SAT Alfisols, the dominance of smectite alongside small amount of kaolinite throughout the solum is also quite common (Chandran et al., 2000). Present SAT climatic conditions are not considered severe enough for transformation and weathering to kaolinite and also for the formation of huge amount of smectite in ferruginous and spatially associated Vertisols (Bhattacharyya et al., 1993; Pal et al., 2012a). Moreover, neutral to alkaline reactions of the present day soils do not favour the transformation of smectite to kaolinite. Therefore, kaolinite was formed in an earlier geological period (pre-Pliocene) with higher rainfall and greater fluctuations in temperature.

Dioctahedral smectite was thus the first weathering product of peninsular gneiss during the HT climate of pre-Pliocene period, but its stability was ephemeral in this climate as evident from its transformation to kaolinite. Both Sm-Kl and smectite could be preserved in such soils because of termination of HT climate during the Plio-Pleistocene transition (Pal et al., 1989). Such SAT Alfisols are spatially associated with Vertisols in the lower topographic positions, and these Vertisols are developed during the dry climate of the Holocene period in the 
(a)

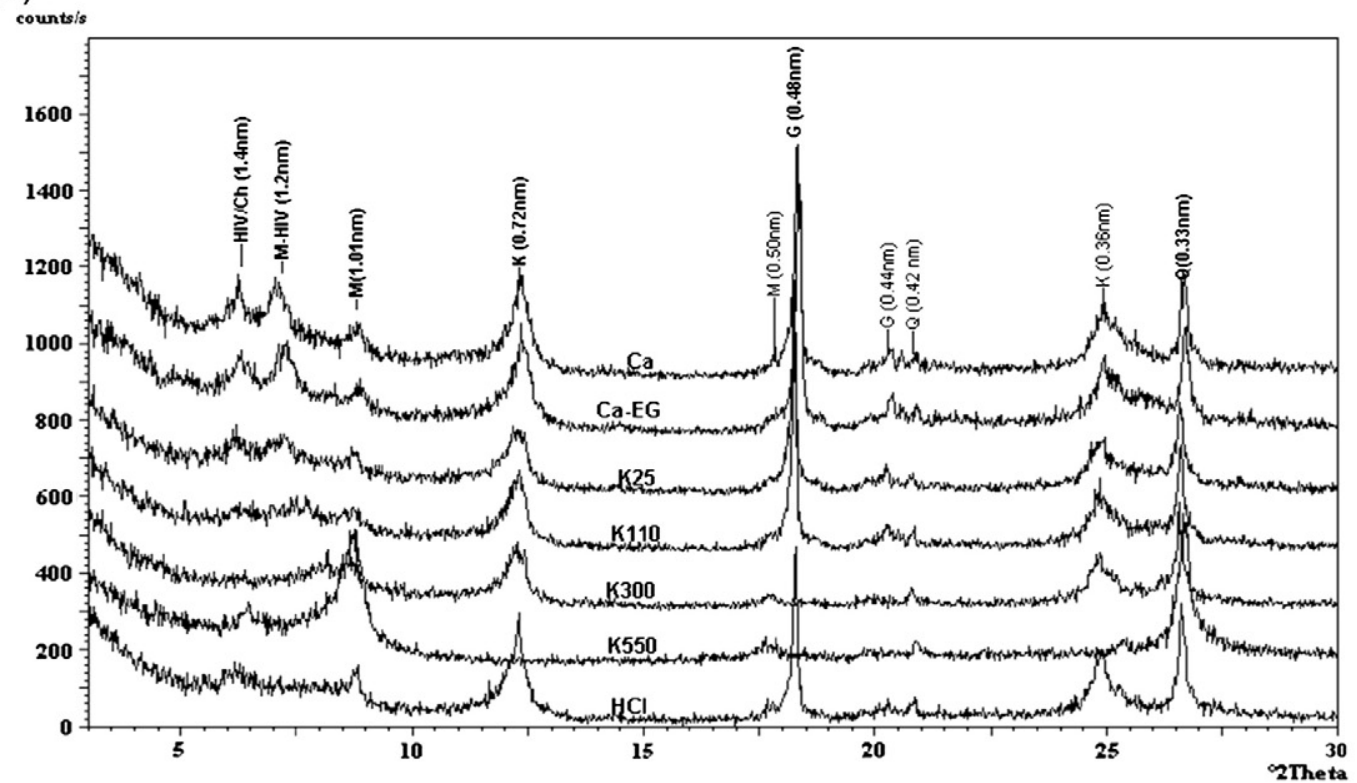

(b)

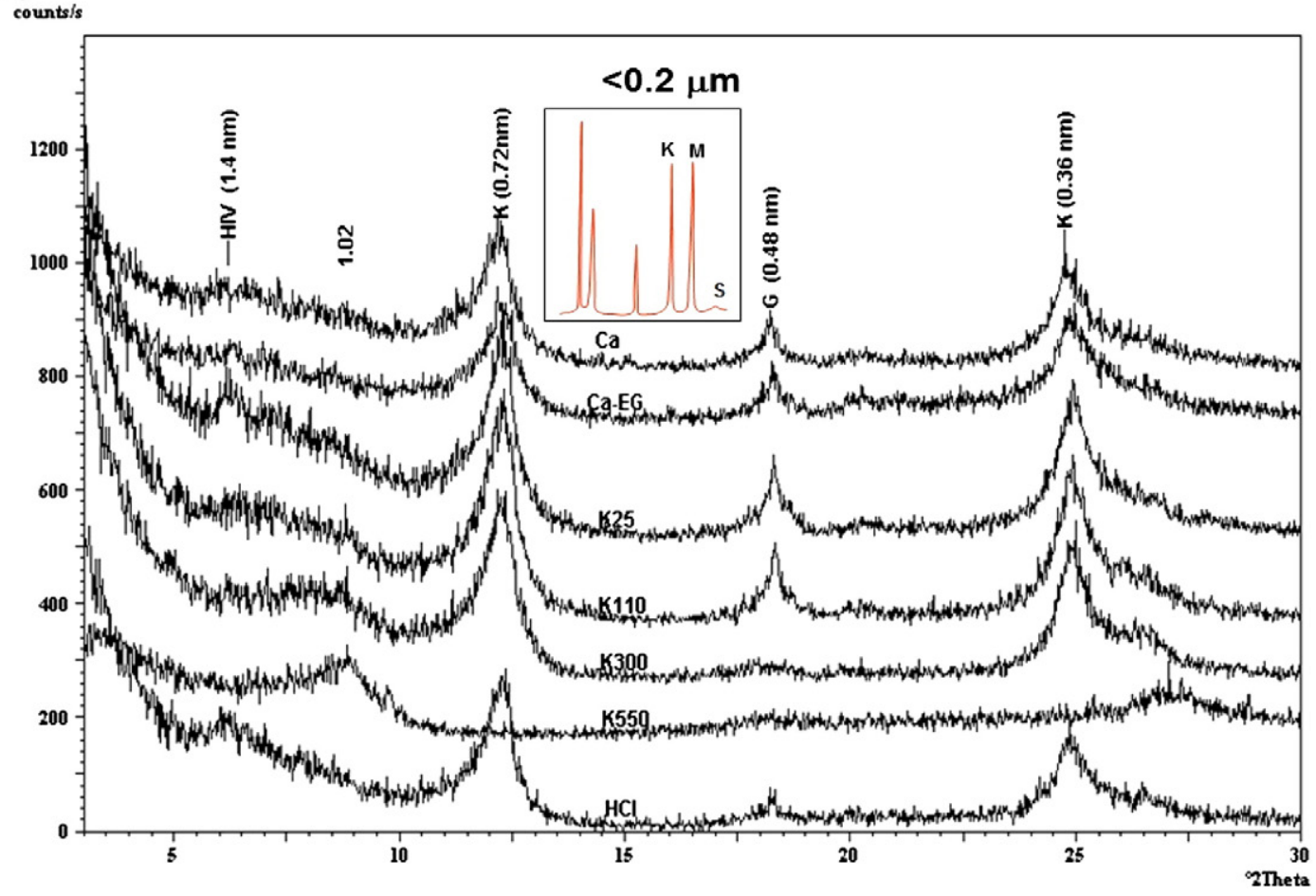

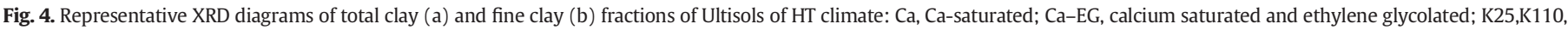

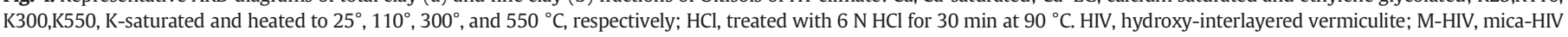

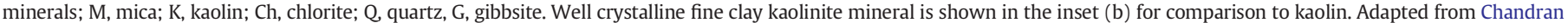
et al. (2005a) and Pal et al. (1989).

deposited smectitic parent material of the previous much wetter climate (Pal et al., 2009). The preservation of the crystallinity of SAT Vertisols' smectite in depressions and the lack of transformation of primary minerals validate the hypothesis of positive entropy change during the formation of Vertisols (Srivastava et al., 2002). Therefore, the formation of such Vertisols also helps to infer climate change in geographical areas covered by the RF soils in the Peninsular India (Pal et al., 2012a).

RF soils of the Peninsular India overlying the saprolites of metamorphic rocks, dominated either by kaolinite or dioctahedral smectite, are relict paleosols (Pal et al., 1989). These relict soils have been affected by the climatic change from humid to semi-arid (SA) climatic conditions during the Plio-Pleistocene transition period. During SA climate trioctahedral smectite was formed from the sand and silt size biotite (Fig. 6a), which survived earlier weathering during the HT climate (Chandran et al., 2000; Pal et al., 1989). In addition, selected such soils show the presence of pedogenic calcium carbonates (PC) as spongy nodules and cluster of carnonets needles below $40 \mathrm{~cm}$ depth (Fig. 6b), indicating their formation in the prevailing SAT environments.

The formation of PC causes the concomitant development of sodicity (Pal et al., 2000b). At present, the rate of formation of PC and the 
(a)

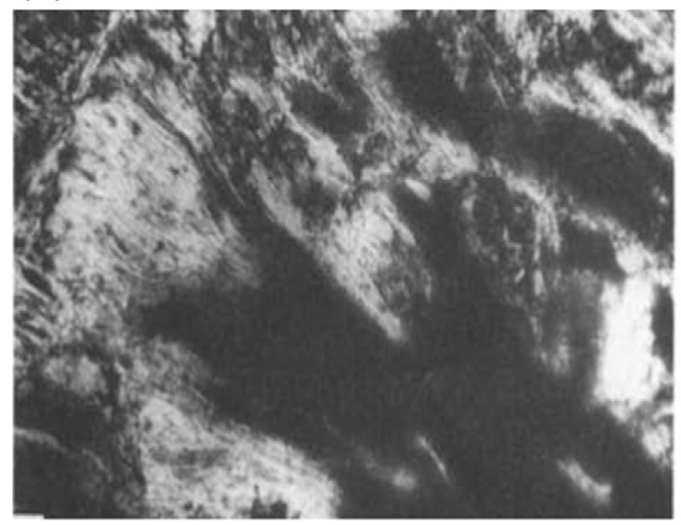

(b)

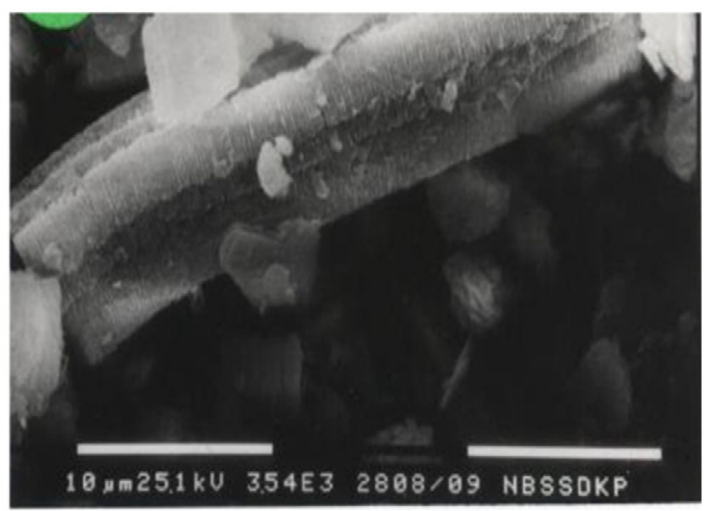

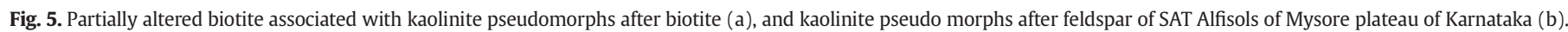
Adapted from Pal et al. (1989, 2002).

development of sodicity in the SAT Alfisols may not be alarming, but the continuation of natural chemical degradation would impair drainage of these soils (Pal et al., 2000a; Srivastava et al., 2001). During the SA climate for millions of years many such soils are at present mildly acidic and calcareous (Bhattacharyya et al., 2009), and their clay enriched B horizons often indicate the presence of impure clay pedofeatures (Venugopal, 1997) along with pure void argillans (Kooistra, 1982; Venugopal et al., 1991; Venugopal, 1997). In the SA climate, the precipitation of $\mathrm{CaCO}_{3}$ facilitates the deflocculation of clay particles and their subsequent translocation and accumulation in the Bt horizons (Pal et al., 2003), but in the presence of various types of other illuvial pedofeatures (Venugopal, 1997), it probably is not prudent to suggest a precise pedogenic process for the formation of poorly oriented (impure) clay pedofeatures. Obviously, there is need for future research in this area.

\section{Acidity and its nature and charge characteristics in RF soils of HT climate}

In the humid tropical regions of India, soil acidity poses a challenge for crop production as the soils are slight to strongly acidic in $\mathrm{pH}$. Rapid weathering of minerals in HT climate and the excessive leaching of soluble salts cause acidity in the surface and sub-surface of soils. Soil acidity develops on soil colloids mainly through isomorphous substitution of $\mathrm{H}^{+}$or $\mathrm{Al}^{3+}$ in silicate minerals, which form exchange sites throughout the $\mathrm{pH}$ ranges - permanent charge acidity (exchangeable acidity), and due to the formation of polymers of Fe and Al with soil organic matter when the exchange sites mainly depend mainly on soil

(a)

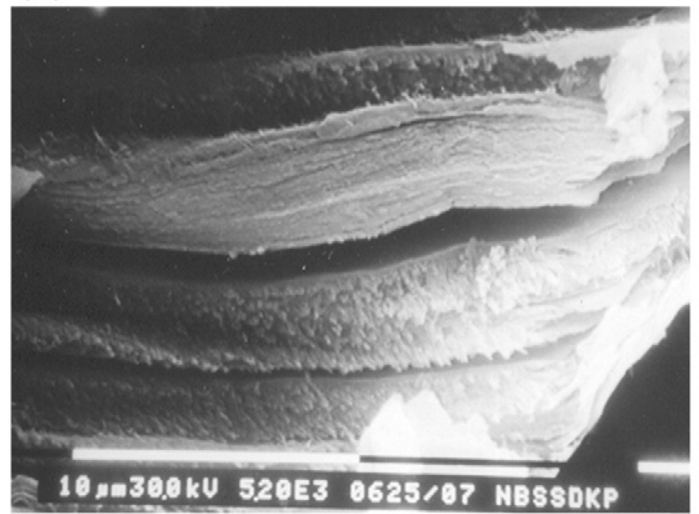

$\mathrm{pH}$ ( $\mathrm{pH}$-dependent acidity). Results of studies made for such soils of Kerala (Chandran et al., 2005a; Krishnan et al., 1996), Goa (Chandran et al., 2004), Karnataka (Shiva Prasad et al., 1998), Tamil Nadu (Natarajan et al., 1997) and NEH (Bhattacharyya et al., 1994, 2000a, 2004; Nayak et al., 1996a; Sen et al., 1994, 1997a,b,c) indicate that $\mathrm{KCl}$ extractable acidity is low but total acidity by $\mathrm{BaCl}_{2}$-TEA is remarkably high (Table 2). Exchange acidity contributes up to 22\%, whereas the $\mathrm{pH}$-dependent acidity contributes about $98 \%$ of the total acidity. High amount of pH-dependent acidity has been attributed to the combined effects of organic matter, free sesquioxides and terminal hydroxyl groups associated with $\mathrm{Si}$ and/or $\mathrm{Al}$, and/or the ruptured $\mathrm{Si}-\mathrm{O}-\mathrm{Al}$ bonds (associated mostly with low activity clays) (Nayak et al., 1996a; Sen et al., 1997a).

The exchangeable $\mathrm{Al}^{3+}$ and $\mathrm{Al}$-saturation increase with decrease in soil $\mathrm{pH}$, and it is almost nil at about $\mathrm{pH}$ around 6.0. $\mathrm{KCl}$ exchangeable acidity in some Ultisols of Kerala (Chandran et al., 2005a), Meghalaya (Bhattacharyya et al., 1994, 2000a) and Alfisols of Goa (Chandran

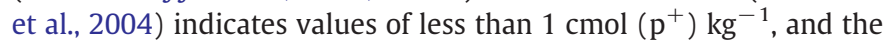
$\mathrm{KCl} \mathrm{pH}$ values of these soils in the lower horizons are close to or greater than $\mathrm{pH}$ values in water (Table 2), suggesting the presence of gibbsite and/or amorphous materials (Smith, 1986). According to the observations in highly weathered Oxisols of Puerto Rico (Beinroth, 1982), these soils are in advanced stage of tropical weathering because such low values of exchange acidity are associated with the presence of gibbsite minerals. However, Bhattacharyya et al. (2000a) and Chandran et al. (2005a) demonstrated that the formation of gibbsite is not possible during the highly acidic weathering conditions of HT climate; and therefore it cannot be taken as an index of advanced stage

(b)

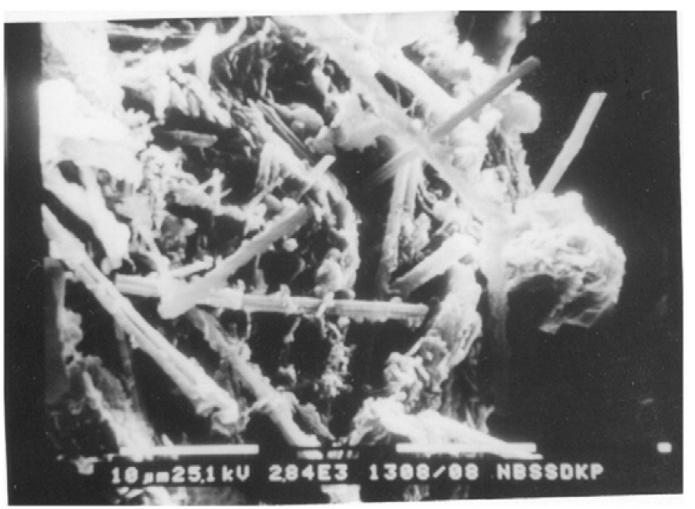

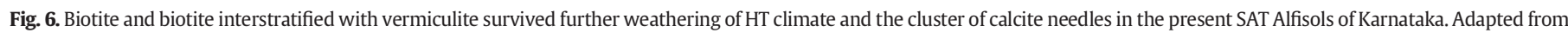
Pal et al. (2000a). 
Table 2

Physical and chemical properties of selected RF soils of HT climate.

\begin{tabular}{|c|c|c|c|c|c|c|c|c|c|c|c|c|c|c|c|}
\hline \multirow[t]{3}{*}{ Horizon } & \multirow[t]{3}{*}{ Depth $\mathrm{cm}$} & \multicolumn{2}{|l|}{$\mathrm{pH}$} & \multirow[t]{3}{*}{$\Delta \mathrm{pH}$} & \multirow[t]{3}{*}{ Clay \% } & \multirow[t]{3}{*}{ Organic carbon \% } & \multicolumn{2}{|c|}{$\begin{array}{l}\text { Exchange acidity } \\
\mathrm{KCl}(\mathrm{N})\end{array}$} & \multirow[t]{3}{*}{$\begin{array}{l}\text { Extractable acidity, } \\
\mathrm{BaCl}_{2} \text {-TEA }\end{array}$} & \multirow[t]{3}{*}{$\begin{array}{l}\mathrm{CEC} \text {, soil } \\
\left(\mathrm{NH}_{4} \mathrm{OAC}, 7\right)\end{array}$} & \multirow[t]{3}{*}{$\begin{array}{l}\text { ECEC, soil } \\
\left(\mathrm{NH}_{4} \mathrm{OAC}, 7\right)\end{array}$} & \multirow[t]{3}{*}{ CEC, clay } & \multirow[t]{3}{*}{ ECEC, clay } & \multirow[t]{3}{*}{ Base saturation, $\%$} & \multirow[t]{3}{*}{$\begin{array}{l}\text { Lime requirement, } \\
\text { t/ha }\end{array}$} \\
\hline & & \multirow[t]{2}{*}{$\overline{\mathrm{H}_{2} \mathrm{O}}$} & \multirow[t]{2}{*}{$\overline{\mathrm{KCl}}$} & & & & $\overline{\mathrm{H}^{+}}$ & $\overline{\mathrm{Al}^{3+}}$ & & & & & & & \\
\hline & & & & & & & \multicolumn{2}{|c|}{$\mathrm{cmol}\left(\mathrm{p}^{+}\right) / \mathrm{kg}$} & & & & & & & \\
\hline \multicolumn{16}{|c|}{ Ustic Kandihumults: Kerala } \\
\hline Ap & $0-13$ & 4.8 & 4.3 & -0.5 & 21.1 & 2.35 & 0.33 & 0.60 & 11.2 & 4.5 & 1.6 & 21.3 & 7.6 & 22 & - \\
\hline Bt1 & $13-32$ & 4.4 & 4.3 & -0.1 & 31.3 & 1.86 & 0.50 & 0.48 & 10.4 & 3.5 & 1.1 & 11.2 & 3.5 & 17 & - \\
\hline Bt2 & $32-56$ & 4.5 & 4.3 & -0.2 & 29.0 & 1.50 & 0.43 & 0.32 & 10.0 & 3.7 & 0.8 & 12.8 & 2.7 & 14 & - \\
\hline Bt3 & $56-83$ & 4.5 & 4.6 & +0.1 & 26.0 & 0.90 & 0.23 & 0.12 & 9.0 & 4.1 & 0.7 & 16.0 & 2.7 & 13 & - \\
\hline Bt4 & $83-112$ & 4.4 & 4.6 & +0.2 & 28.5 & 1.11 & 0.20 & 0.10 & 6.6 & 4.0 & 0.6 & 13.7 & 2.1 & 13 & - \\
\hline Bt5 & $112-150$ & 4.7 & 4.7 & Nil & 24.0 & 1.22 & 0.30 & 0.10 & 7.0 & 4.0 & 0.7 & 16.7 & 3.0 & 17 & - \\
\hline \multicolumn{16}{|c|}{ Kanhaplohumults: Arunachal Pradesh ${ }^{b}$} \\
\hline A1 & $0-13$ & 4.6 & 3.8 & -0.8 & 53.0 & 2.70 & 2.0 & 0.7 & 23.3 & 13.2 & 4.8 & 23.0 & 9.2 & 16 & 3.6 \\
\hline Bt1 & $13-36$ & 4.8 & 3.8 & -0.7 & 66.0 & 1.96 & 2.2 & 1.0 & 18.5 & 12.3 & 4.1 & 18.6 & 6.2 & 18 & 4.6 \\
\hline Bt21 & $36-63$ & 5.0 & 4.5 & -0.8 & 68.0 & 0.87 & 2.4 & 1.0 & 14.2 & 10.5 & 4.0 & 15.4 & 6.0 & 16 & 5.1 \\
\hline Bt22 & $63-100$ & 5.4 & 4.2 & -0.8 & 65.0 & 0.64 & 2.6 & 1.1 & 14.3 & 9.7 & 4.4 & 15.0 & 6.8 & 17 & 5.4 \\
\hline B3 & $100-125$ & 5.2 & 4.2 & -1.0 & 47.5 & 0.29 & 2.7 & 1.1 & 10.2 & 7.1 & 4.4 & 15.0 & 9.3 & 18 & 5.4 \\
\hline \multicolumn{16}{|c|}{ Kanhaplohumults: Assam ${ }^{b}$} \\
\hline A1 & $0-14$ & 5.0 & 3.8 & -1.2 & 48.5 & 2.20 & 1.4 & 0.4 & 16.1 & 11.0 & 5.6 & 22.4 & 11.5 & 34 & 2.1 \\
\hline Bt11 & $14-33$ & 4.8 & 3.7 & -1.1 & 56.5 & 1.60 & 2.2 & 0.9 & 16.0 & 10.5 & 5.6 & 18.6 & 10.0 & 24 & 4.3 \\
\hline Bt12 & $33-85$ & 5.1 & 3.8 & -1.3 & 62.0 & 1.00 & 2.0 & 0.9 & 13.0 & 9.0 & 4.4 & 14.3 & 7.1 & 17 & 4.5 \\
\hline Bt21 & $85-120$ & 5.2 & 4.0 & -1.2 & 65.5 & 0.70 & 1.5 & 0.6 & 12.2 & 7.7 & 4.0 & 11.7 & 6.0 & 21 & 3.2 \\
\hline $\mathrm{BC}$ & $120-180$ & 5.4 & 4.0 & -1.4 & 63.5 & 0.50 & 1.3 & 0.5 & 12.0 & 6.5 & 3.1 & 10.2 & 5.0 & 19 & 2.6 \\
\hline \multicolumn{16}{|c|}{ Typic Dystrochrepts: Assam ${ }^{b}$} \\
\hline $\mathrm{A} 1$ & $0-13$ & 5.0 & 3.9 & -1.1 & 29.5 & 1.50 & 1.4 & 0.3 & 10.7 & 10.0 & 5.4 & 32.5 & 18,2 & 37 & 1.3 \\
\hline A2 & $13-31$ & 4.8 & 3.9 & -0.9 & 34.5 & 0.80 & 2.3 & 0.9 & 9.3 & 7.5 & 5.5 & 21.7 & 16.0 & 30 & 4.3 \\
\hline B21 & $31-70$ & 4.9 & 3.9 & -1.0 & 34.0 & 0.66 & 2.1 & 0.7 & 10.6 & 7.0 & 4.8 & 20.3 & 14.0 & 22 & 3.6 \\
\hline B22 & $70-122$ & 4.7 & 4.1 & -0.6 & 44.5 & 0.57 & 2.1 & 0.7 & 10.7 & 8.1 & 4.6 & 18.2 & 10.0 & 18 & 3.6 \\
\hline B3 & $122-175$ & 5.0 & 4.1 & -0.9 & 29.0 & 0.32 & 1.5 & 0.4 & 11.6 & 5.3 & 3.3 & 18.2 & 12.2 & 29 & 2.2 \\
\hline \multicolumn{16}{|c|}{ Typic Dystrochrepts: Manipur ${ }^{b}$} \\
\hline $\mathrm{A} 1$ & $0-10$ & 4.0 & 3.6 & -0.4 & 35.0 & 1,60 & 2.4 & 1.1 & 10.5 & 9.2 & 7.8 & 26.3 & 22.3 & 51 & 5.3 \\
\hline A2 & $10-28$ & 4.0 & 3.6 & -0.4 & 40.0 & 1.20 & 2.9 & 1.4 & 8.7 & 8.1 & 6.3 & 20.2 & 15.7 & 28 & 6.7 \\
\hline B21 & $28-60$ & 4.2 & 3.8 & -0.4 & 40.5 & 0.70 & 3.3 & 1.5 & 8.8 & 8.0 & 5.8 & 19.5 & 14.3 & 26 & 7.6 \\
\hline B22 & $60-90$ & 4.2 & 3.8 & -0.4 & 39.0 & 0.60 & 3.1 & 1.5 & 8.6 & 7.6 & 5.5 & 19.5 & 14.0 & 30 & 7.4 \\
\hline BC & $90-125$ & 4.2 & 3.9 & -0.3 & 28.0 & 0.30 & 2.7 & 1.3 & 6.5 & 7.8 & 5.0 & 27.8 & 17.5 & 13 & 6.4 \\
\hline
\end{tabular}


Table 2 (continued)

\begin{tabular}{|c|c|c|c|c|c|c|c|c|c|c|c|c|c|c|}
\hline \multirow[t]{3}{*}{ Horizon } & \multirow[t]{3}{*}{ Depth cm } & \multicolumn{2}{|l|}{$\mathrm{pH}$} & \multirow[t]{3}{*}{$\Delta \mathrm{pH}$} & \multirow[t]{3}{*}{ Clay \% } & \multirow[t]{3}{*}{ Organic carbon \% } & $\begin{array}{l}\text { Exchange acidity } \\
\mathrm{KCl}(\mathrm{N})\end{array}$ & \multirow[t]{3}{*}{$\begin{array}{l}\text { Extractable acidity, } \\
\mathrm{BaCl}_{2} \text {-TEA }\end{array}$} & \multirow[t]{3}{*}{$\begin{array}{l}\text { CEC, soil } \\
\left(\mathrm{NH}_{4} \mathrm{OAC}, 7\right)\end{array}$} & \multirow[t]{3}{*}{$\begin{array}{l}\text { ECEC, soil } \\
\left(\mathrm{NH}_{4} \mathrm{OAC}, 7\right)\end{array}$} & \multirow[t]{3}{*}{ CEC, clay } & \multirow[t]{3}{*}{ ECEC, clay } & \multirow[t]{3}{*}{ Base saturation, \% } & \multirow[t]{3}{*}{$\begin{array}{l}\text { Lime requirement, } \\
\text { t/ha }\end{array}$} \\
\hline & & $\mathrm{H}_{2} \mathrm{O}$ & $\mathrm{KCl}$ & & & & $\mathrm{Al}^{3+}$ & & & & & & & \\
\hline & & & & & & & $\mathrm{cmol}\left(\mathrm{p}^{+}\right) / \mathrm{kg}$ & & & & & & & \\
\hline
\end{tabular}

\begin{tabular}{|c|c|c|c|c|c|c|c|c|c|c|c|c|c|c|c|}
\hline \multicolumn{16}{|c|}{ Typic Kandihumults: Meghalaya ${ }^{b}$} \\
\hline A1 & $0-16$ & 4.5 & 4.2 & -0.3 & 21.6 & 3.6 & 1.14 & 0.36 & 32.0 & 7.3 & 2.5 & 33.8 & 16.6 & 19 & 1.8 \\
\hline B21 & $16-31$ & 4.8 & 4.4 & -0.4 & 30.4 & 2.5 & 0.64 & 0.16 & 27.0 & 7.3 & 3.0 & 24.0 & 10.0 & 20 & 0.8 \\
\hline B22 & $31-62$ & 5.0 & 4.8 & -0.2 & 31.1 & 2.0 & 0.30 & Nil & 22.0 & 4.1 & 0.8 & 13.2 & 2.6 & 19 & Nil \\
\hline B23 & $62-95$ & 5.1 & 6.4 & +0.9 & 26.5 & 0.6 & 0.10 & Nil & 15.8 & 4.1 & 1.2 & 15.5 & 4.5 & 29 & Nil \\
\hline \multicolumn{16}{|c|}{ Typic Hapludults: Mizoram ${ }^{b}$} \\
\hline A1 & $0-27$ & 4.7 & 3.8 & -0.9 & 37.0 & 1.00 & 3.27 & 1.53 & 14.3 & 10.6 & 6.8 & 28.6 & 18.3 & 19 & 7.6 \\
\hline Bt1 & $27-50$ & 4.7 & 3.8 & -0.9 & 45.0 & 0.80 & 3.43 & 1.57 & 12.7 & 10.0 & 6.2 & 22.7 & 14.5 & 13 & 7.7 \\
\hline Bt2 & $50-110$ & 4.9 & 3.8 & -1.1 & 50.0 & 0.60 & 3.53 & 1.67 & 14.3 & 10.3 & 6.6 & 20.6 & 13.2 & 14 & 8.2 \\
\hline BC & $110-180$ & 5.0 & 3.9 & -1.1 & 36.5 & 0.40 & 2.33 & 1.07 & 12.0 & 7.3 & 5.3 & 20.0 & 14.3 & 19 & 5.3 \\
\hline \multicolumn{16}{|c|}{ Typic Hapludults: Nagaland ${ }^{b}$} \\
\hline $\mathrm{A} 1$ & $0-15$ & 5.5 & 4.1 & -1.4 & 33.0 & 1.40 & 0.54 & 0.06 & 10.3 & 11.4 & 8.0 & 34.5 & 24.4 & 65 & 0.3 \\
\hline Bt1 & $15-30$ & 5.1 & 3.6 & -1.5 & 44.0 & 0.70 & 1.74 & 0.76 & 12.0 & 10.0 & 7.0 & 22.7 & 16.1 & 47 & 3.8 \\
\hline Bt21 & $30-46$ & 5.1 & 3.6 & -1.5 & 55.5 & 0.60 & 3.00 & 1.40 & 12.4 & 12.4 & 9.3 & 22.3 & 16.7 & 39 & 6.9 \\
\hline Bt22 & $46-71$ & 5.2 & 3.5 & -1.7 & 68.0 & 0.50 & 4.33 & 2.07 & 15.0 & 14.5 & 11.6 & 21.3 & 17.0 & 35 & 10.2 \\
\hline Bt31 & $71-100$ & 5.2 & 3.5 & -1.7 & 67.5 & 0.40 & 4.84 & 2.36 & 17.0 & 15.0 & 12.1 & 22.0 & 20.0 & 38 & 11.7 \\
\hline Bt32 & $100-125$ & 5.3 & 3.5 & -1.8 & 64.5 & 0.30 & 4.70 & 2.30 & 17.1 & 13.3 & 12.0 & 20.6 & 18.6 & 46 & 11.4 \\
\hline \multicolumn{16}{|c|}{ Typic Paleudults: Tripura ${ }^{b}$} \\
\hline A1 & $0-11$ & 4.7 & 3.9 & -0.7 & 18.5 & 0.70 & 1.5 & 0.67 & 7.3 & 5.8 & 4.1 & 31.3 & 22.2 & 33 & 3.3 \\
\hline Bt1 & $11-38$ & 4.5 & 3.8 & -0.7 & 29.5 & 0.60 & 2.3 & 1.13 & 7.4 & 6.6 & 4.9 & 22.4 & 16.3 & 21 & 5.6 \\
\hline Bt2 & $38-83$ & 4.6 & 3.9 & -0.7 & 35.5 & 0.40 & 2.3 & 1.10 & 8.8 & 7.0 & 4.9 & 19.7 & 13.9 & 22 & 5.4 \\
\hline Bt3 & $83-172$ & 4.8 & 3.9 & -0.9 & 36.0 & 0.30 & 2.2 & 1.03 & 10.9 & 7.4 & 4.5 & 20.5 & 12.5 & 17 & 5.1 \\
\hline \multicolumn{16}{|c|}{ Kandic Paleustalfs: Goa ${ }^{c, d}$} \\
\hline A & $0-8$ & 5.4 & 4.6 & -0.8 & 46.2 & 5.04 & 0.17 & 0.05 & 19.0 & 19.0 & 7.6 & 41.1 & 16.4 & 40 & - \\
\hline A2 & 8-19 & 5.3 & 4.4 & -0.9 & 62.2 & 2.52 & 0.19 & 0.37 & 19.6 & 15.7 & 6.8 & 25.0 & 11.0 & 41 & - \\
\hline Bt1 & $19-51$ & 5.2 & 4.4 & -0.8 & 57.2 & 2.01 & 0.21 & 0.41 & 18.0 & 16.2 & 6.6 & 28.3 & 11.5 & 38 & - \\
\hline Bt2 & $51-89$ & 5.2 & 4.4 & -0.8 & 65.2 & 1.47 & 0.22 & 0.38 & 16.5 & 14.3 & 6.9 & 22.0 & 10.6 & 45 & - \\
\hline $\mathrm{Cr}$ & $89+$ & - & & & & & & & & & & & & & \\
\hline \multicolumn{16}{|c|}{ Pachic Argiustoll: Kerala ${ }^{e}$} \\
\hline A & $0-19$ & 5.1 & - & - & 22.7 & 1.80 & - & - & - & 15.4 & - & 67.8 & - & 64 & - \\
\hline Bt1 & $19-53$ & 6.4 & - & - & 22.6 & 1.28 & - & - & - & 13.7 & - & 60.6 & - & 61 & - \\
\hline Bt2 & $53-81$ & 6.4 & - & - & 23.0 & 0.38 & - & - & - & 10.8 & - & 47.0 & - & 74 & - \\
\hline Bt3 & $81-115$ & 6.5 & - & - & 20.8 & 0.40 & - & - & - & 9.7 & - & 46.6 & - & 73 & - \\
\hline Bt4 & 115-155 & 6.4 & - & - & 22.7 & 0.34 & - & - & 8.82 & 8.6 & & 38.0 & & 76 & - \\
\hline
\end{tabular}

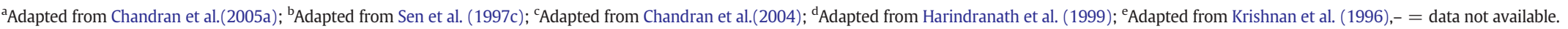


(a)

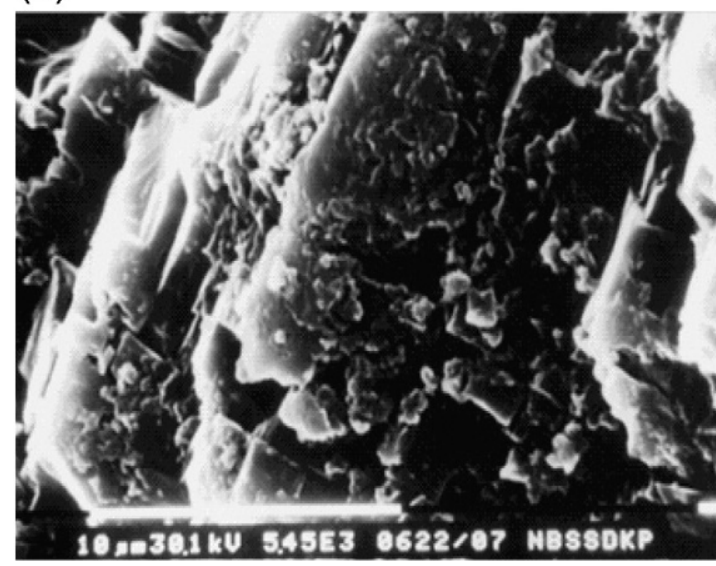

(b)

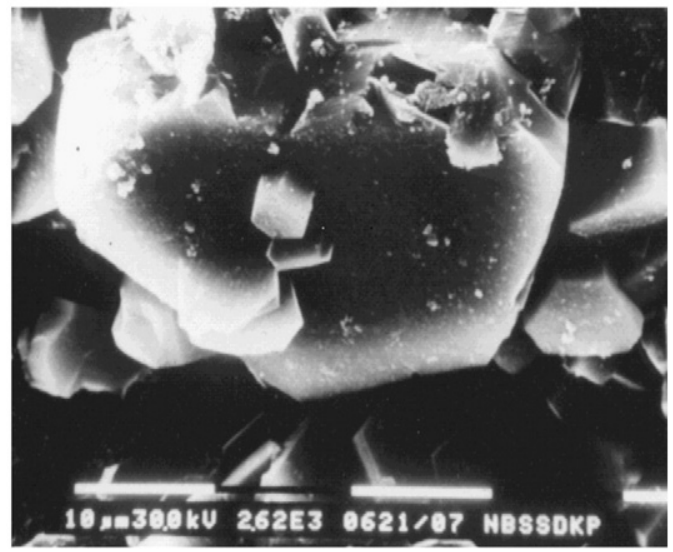

(c)

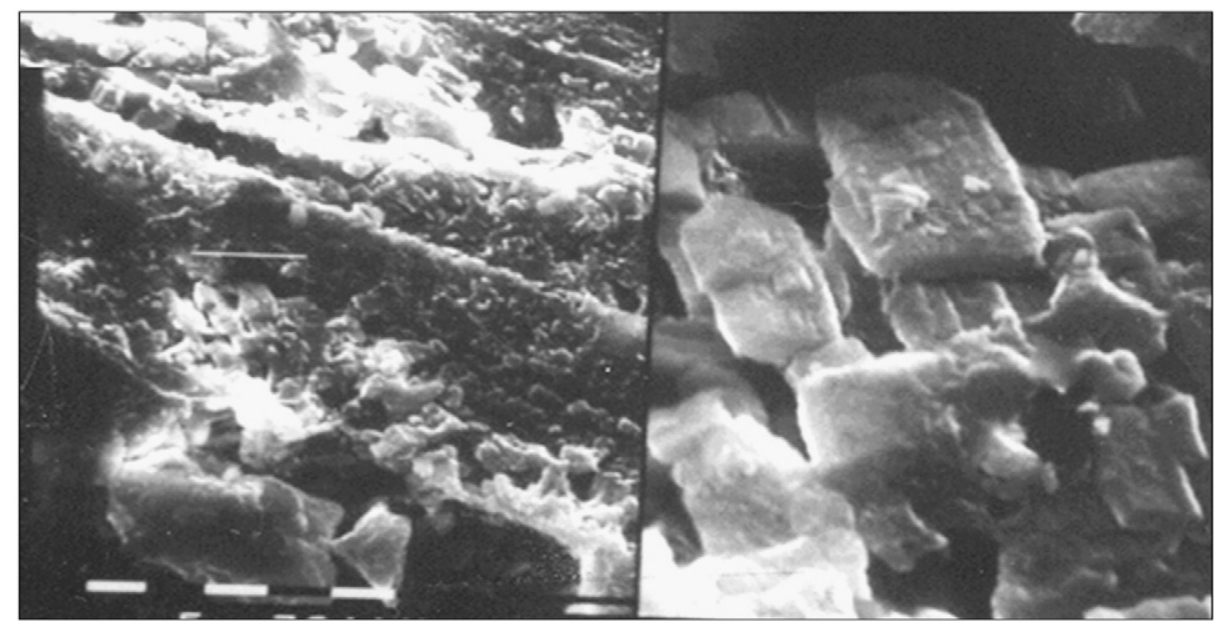

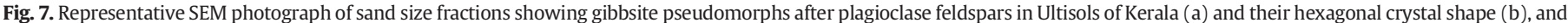

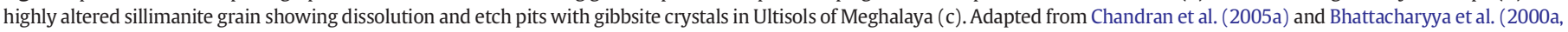
2000b).

of tropical weathering. In non-gibbsitic Ultisols and Inceptisols of NEH, KCL exchangeable acidity is 3 to 4 times higher values than unity (Bhattacharyya et al., 1994; Nayak et al., 1996a; Sen et al., 1997a).

Low amount of $\mathrm{KCl}$ extractable acidity (due to $\mathrm{H}^{+}$and $\mathrm{Al}^{3+}$ ions) indicates that considerable amount of $\mathrm{Al}^{3+}$ released during humid tropical weathering is trapped in clay minerals other than kaolinite, which is not easily extractable by $1 \mathrm{~N}$ unbuffered $\mathrm{KCl}$ solution (Chandran et al., 2004, 2005b). The LAC soils have kaolinitic mineralogy class according to the CEC of soils $\left(<16 \mathrm{cmol}(\mathrm{p}+) \mathrm{kg}^{-1}\right)$ and ECEC of clays $\left(<12 \mathrm{cmol}(\mathrm{p}+) \mathrm{kg}^{-1}\right)$ (Bhattacharyya et al., 1994; Eswaran et al., 1992b; Kharche, 1996; Krishnan et al., 1996; Natarajan et al., 1997; Nayak et al., 1996a; Sen et al., 1994, 1997a,b,c; Shiva Prasad et al., 1998).

\section{Mineralogy of RF soils of the HT climate}

Many believe that tropical soils as those of the hot and humid tropics, exemplified by deep red and highly weathered soils (Eswaran et al., 1992a) are not conducive for plant growth and productivity (Aleva, 1994) because of their kaolinitic/gibbsitic mineralogy (Schwertmann and Herbillon, 1992) associated with Fe and Al toxicity (Sehgal, 1998). Recent research using X-ray diffraction (XRD) and scanning electron microscopy (SEM) on soil particle size fractions of the acidic bench mark RF soils (Ultisols, Alfisols and Inceptisols) of the humid tropical climate of India in the states of Maharashtra (Bhattacharyya et al., 1993, 1999), Madhya Pradesh (Bhattacharyya et al., 2005, 2006a), Karnataka
(Kharche, 1996), Kerala (including soils very close to Angadipuram the type locality of laterite, a name first coined by Francis Buchanan in 1800, Chandran et al., 2005a), Goa (Chandran et al., 2004), Jharkhand (Ray et al., 2001), Meghalaya (Bhattacharyya et al., 2000a), Tripura (Bhattacharyya et al., 2006b), Manipur (Chandran et al., 2006), Assam (Pal et al., 1987) and Andaman and Nicobar islands (Chandran et al., 2005b) indicates the dominant presence of kaolin (Kl-HIV/HIS) (a $0.7 \mathrm{~nm}$ mineral interstratified with hydroxy-interlayered vermiculite, HIV or smectite, HIS) with occasional presence of gibbsite (Figs. 3 and $4 \mathrm{a}, \mathrm{b})$. The presence of kaolin is in contrast to the general perception that these soils are dominated by kaolinite and/or gibbsite. These soils also contain considerable amounts of weatherable minerals (>10\%) like mica, mica-hydroxy-interlayered smectite (M-HIS), and hydroxyinterlayered vermiculite/smectite (HIV/HIS) (Chandran et al., 2004, 2005a)

\subsection{Genesis of kaolinite and gibbsite}

XRD of $\mathrm{Ca} / \mathrm{Mg}$-saturated silt, total clay and fine clay fractions on glycolation shows a characteristic $0.7 \mathrm{~nm}$ peak of kaolin, which has a broad base tailing towards the low angle side with branching at the tips (Figs. 3 and 4a.b). This indicates it is not a discrete kaolinite because on K-saturation and heating at $550{ }^{\circ} \mathrm{C}$, the $0.7 \mathrm{~nm}$ peaks disappear reinforcing the $1.0 \mathrm{~nm}$ region of mica. The presence of mica, M-HIV (occasional), HIS and HIV in the silt and clay fractions indicates that mica has been transformed into vermiculite and then to HIV in soils 
developed from the metamorphic rocks (Bhattacharyya et al., 2000a, 2006b; Chandran et al., 2004, 2005a,b, 2006; Pal et al., 1987; Ray et al., 2001).

In RF soils developed on the Deccan basalt, smectite is first transformed to HIS and then to kaolin (Kl-HIS) (Bhattacharyya et al., 1993, 1999,2005 ) (Fig. 3). The $\mathrm{Al}^{3+}$ released during tropical weathering is adsorbed in the interlayers of smectites to form HIS and further to kaolin (Kl-HIS). In an acid weathering environment induced by the HT climate with abundant $\mathrm{Al}^{3+}$, hydroxy-Al-interlayering in the expansible clay minerals is the primary reaction towards the interstratifications of $2: 1$ and 1:1 layers (Bhattacharyya et al., 1997; Pal et al., 1989) and therefore, such interstratified minerals are so common in RF soils of the present and past HT climate (Bhattacharyya et al., 1997; Pal et al., 1989). According to 'antigibbsite effect' (Jackson, 1963, 1964) so long as the formation of HIV/HIS continues, formation of gibbsite is improbable. In contrast, Ultisols and Alfisols of HT climate of India gibbsite and HIV/HIS occur simultaneously. However, the presence of gibbsite is not a common occurrence in soils of the HT climate, and it was only detected in Ultisols of Kerala (Chandran et al., 2005a), Alfisols of Goa (Chandran et al., 2004), Alfisols and Ultisols of Karnataka (Kharche, 1996) and Ultisols of Meghalaya (Bhattacharyya et al., 2000a).

Well-developed gibbsite as hexagonal crystals are observed under SEM, and they are pseudomorphs after feldspars (Fig. 7a, b) in Ultisols of Kerala, and sillimanite grains in Ultisols of Meghalaya (Fig. 7c). Tait et al. (1983) reported the formation of gibbsite in an alkaline environment. Gibbsite is also a common occurrence in alkaline environment of natural bauxite (Balasubramaniam and Sabale, 1984). Therefore, the formation of gibbsite and HIV/HIS occurs in two different chemical environments. The resultant clay mineral during the prolonged tropical weathering in an acidic environment is kaolin (Kl-HIV/HIS) and further desilication of this mineral is not operative at present because the $\mathrm{pH}$ is much below the threshold of $\sim 9$ (Millot, 1970). Thus the ratios of $\mathrm{SiO}_{2}$ : $\mathrm{R}_{2} \mathrm{O}_{3}$ (1.4-5.0) and $\mathrm{SiO}_{2}: \mathrm{A}_{2} \mathrm{O}_{3}(1.8-6.0)$ in Ultisols (Chandran et al., 2005a; Varghese and Byju, 1993) and Alfisols (Chandran et al., 2004) indicate their siliceous nature, suggesting an incomplete desilication process.

The amount of $\mathrm{SiO}_{2}$ and its molar ratios in the Alfisols and Ultisols are comparable with some of the Oxisols of Puerto Rico (Jones et al., 1982), Brazil (Buurman et al., 1996; Muggler, 1998), and other regions of the World (Mohr et al., 1972). Transformation of kaolinite to gibbsite in acidic $\mathrm{pH}$ soils does not seem possible since kaolinite is in the intermediate weathering stage, and not yet fully transformed to kaolinite. This particular weathering pathway suggests that gibbsite was formed in a neutral to slightly alkaline $\mathrm{pH}$ range and the kaolin in an acidic $\mathrm{pH}$ (Bhattacharyya et al., 2000a).

Balasubramaniam and Sabale (1984) also suggested that kaolinization is not an intermediate stage in the formation of bauxite. Gibbsite was formed directly from plagioclase feldspars and sillimanite in an alkaline environment. It is intriguing to note that highly acidic Alfisols and Ultisols of humid tropical Indian environment show the presence of gibbsite in soils only few states of India (Kerala, Goa, Karnataka and Meghalaya) and their $\mathrm{KCl}$ extractable acidity $\left(\mathrm{H}^{+}\right.$and $\left.\mathrm{Al}^{+3}\right)$ is much less as compared to that in other Ultisols of NEH that do not contain gibbsite (Table 2). Thus, a new research initiative to resolve this enigma is warranted.

Both Alfisols and Ultisols of the HT climate contain biotite particles which survived even in kaolin dominated RF soils (Bhattacharyya et al., 2000a; Chandran et al., 2005a; Pal et al., 1989). Under both optical and electron microscope examination, no gibbsite particles were observed at the fringes of biotite particles. Instead, the biotites show the initiation of layer separation due to the formation of vermiculite (Fig. 6a). Although biotites were not lost totally through their dissolution in alkaline environment (Pal, 1985), feldspars/sillimanite and biotites were dissolved during the initial stage of weathering to produce $\mathrm{Al}$ in soil solution, which then crystallized as gibbsite on solid mineral surfaces. Observations on the dissolution and etch pits of feldspar/sillimanite under electron microscope indicated the formation of gibbsite primarily from feldspar/sillimanite (Fig. 7a,b,c) (Bhattacharyya et al., 2000a; Chandran et al., 2005a). These results confirm the formation of gibbsite at the expense of primary aluminosilicate minerals is a common phenomenon in soils (Hsu, 1989; Lowe, 1986).

During progressive weathering, soil $\mathrm{pH}$ became acidic and the released $\mathrm{Al}$ ions as $\mathrm{Al}(\mathrm{OH})_{2}^{+}$ions were adsorbed in the interlayer spaces to neutralize the negative charge of vermiculites/smectites, and to transform them into HIVs/HISs. The presence of HIV alongside Kl-HIV and M-HIV in Ultisols of Kerala, Karnataka, Meghalaya and Alfisols of Goa confirms that following the formation of gibbsite during the initial alkaline weathering, soils later experienced acidic weathering to form HIV, and finally to Kl-HIV (kaolin). Recognizing the different pathways of formation of kaolinite and gibbsite, it is clear that the genesis of gibbsite is not a contemporary pedogenic event in the continuing acidic humid tropical weathering environment; and thus, its presence in soils should not be considered as a conclusive proof of extreme weathering conditions of soils.

\subsection{Rationale for mineralogy class for RF soils of HT climate}

Kaolinitic mineralogy class is assigned to many Alfisols and Ultisols of Kerala, Karnataka and Tamil Nadu (Bhattacharyya et al., 2009) based on their clay CEC and ECEC values which are less than 16 and $12 \mathrm{cmol}\left(\mathrm{p}^{+}\right) \mathrm{kg}^{-1}$, respectively (Smith, 1986). But the prevailing acid weathering causes hydroxy interlayering of vermiculites/smectites of these soils. Thus, the acidity of soils determined by $\mathrm{BaCl}_{2}$-TEA is much higher than that determined by using $1 \mathrm{~N} \mathrm{KCl}$. This total acidity plus the sum of bases by $\mathrm{NH}_{4} \mathrm{OAc}$ ( $\mathrm{pH} 7$ ) (clay CEC of sum of cations in soil control section) indicates a value much greater than 12 (Chandran et al., 2005a). Based on the semi-quantitative estimates of gibbsite in the $<2 \mathrm{~mm}$ fraction and also in soil control section of few bench mark Ultisols of Kerala might have either gibbsitic/allitic mineralogy class as per the US Soil Taxonomy. However, in view of the genesis of gibbsite and kaolin in Ultisols of Kerala (Chandran et al., 2005a) and Meghalaya (Bhattacharyya et al., 2000a), it would be prudent not to consider the gibbsitic/allitic mineralogy class for Ultisols and Oxisols as such mineralogy class would undermine the contemporary pedogenesis of the formation of various hydroxy-interlayered clay minerals. Therefore, the most appropriate mineralogy class for Ultisols should be 'mixed' as this class appears to be compatible with their use for horticultural, forestry and agricultural crops at the present time.

\section{Ultisols of humid tropical climate of India in context with global Oxisols}

According to Buol and Eswaran (2000) the term 'laterite' is equivalent to Oxisols in the US Soil Classification System. The primary requirement for Oxisols is the oxic horizon with low CEC, low ECEC, and less than $10 \%$ weatherable minerals. Oxisols are formed in tropical climate, stable landscape, and siliceous/acidic parent material. There are geographical areas in India such as in Kerala, and parts of Karnataka and Tamil Nadu in southern India, Goa in the western India, the Western Ghats of India, the NEH and the Andaman and Nicobar Islands that fulfil all the requirements for the formation of Oxisols. It is however clear that the soils of these geographical areas under HT climate have not reached the stage of Oxisols (Bhattacharyya et al., 1993, 2009). Instead, the soils have kaolinite and other hydroxy-interlayered minerals, and represent highly acidic Ultisols, and mildly acidic to neutral Alfisols and Mollisols. This demands a further critique of the published literature on Oxisols.

For the Oxisols of Puerto Rico a high amount of extractable acidity was reported by Beinroth (1982), which is not in accordance with the dominant presence of gibbsite and kaolinite (Jones et al., 1982) because the extractable acidity is related to the hydroxy-interlayered 2:1 layer silicate minerals. Therefore, the presence of hydroxy-interlayered minerals could be expected in such soils, which was confirmed by the 
reported adsorption of moderate amount of added $\mathrm{K}$ (Fox, 1982). It is speculated that Oxisols of Puerto Rico contain small to moderate amounts of vermiculite and/or HIV, which are exclusively capable of $\mathrm{K}$ adsorption. Macedo and Bryant (1987) reported the occurrence of Oxisols in Brazil. However, a further examination of chemical data indicates that the basic requirements of an oxic horizon are not fulfilled because these soils have clay CEC $>16 \mathrm{cmol}\left(\mathrm{p}^{+}\right) \mathrm{kg}^{-1}$. Thus, the placement of these soils in Oxisol order cannot be well defined. Later Buurman et al (1996) and Muggler (1998) reported results on pH and CEC of selected Oxisols, which range from 5.0 to 5.5 and 4 to $6 \mathrm{cmol}$ $\left(\mathrm{p}^{+}\right) \mathrm{kg}^{-1}$, respectively. But the exchangeable bases and extractable $\mathrm{Al}$ in most of these soils (except the surface horizons) were reported zero. Based on these results, the ECEC and base saturation are also zero. Such a chemical environment is paradoxical, especially when the soils are still siliceous as they contain $30-50 \% \mathrm{SiO}_{2}$ and support maize cultivation. Thus, this critique brings out that the placement of these soils in Oxisols order is hardly justified.

\section{Modelling RF soils developed in HT climate of India}

Under the HT climate, soils formed are not similar in nature and they belong to three major soil orders of Ultisols, Alfisols and Mollisols. Mollisols are prevalent under thick forest vegetation, whereas Alfisols are sparse forest vegetation and/or in agricultural soils (Bhattacharyya et al., 2005; Krishnan et al., 1996; Natarajan et al., 1997; Shiva Prasad et al., 1998) and Ultisols are in general under agriculture (Bhattacharyya et al., 2000a; Kharche, 1996; Krishnan et al., 1996; Sen et al., 1997a). However, there are strongly acidic Ultisols and mildly acidic to neutral Alfisols and Mollisols. In the zeolite Deccan basalt area in Central India (Satpura Range) and Western Ghats regions, moderately acidic Alfisols are spatially associated with moderately acidic Mollisols (Bhattacharyya et al., 2005).

In Goa on gneissic rock, strongly acidic Ultisols are associated with moderately acidic Alfisols (Chandran et al., 2004; Harindranath et al., 1999). In Karnataka on gneissic rock in the Western Ghats area, moderately acidic Ultisols, Alfisols and Mollisols are spatially associated (Shiva Prasad et al., 1998). In the Nilgiri Hills areas of Tamil Nadu on gneissic rock, strongly acidic Ultisols are spatially associated with mildly acidic Alfisols and Mollisols (Natarajan et al., 1997). In Nilgiri hills areas in Kerala on calc-gneiss, near the north of the Palghat Gap strongly acidic Ultisols are associated with mildly acidic to neutral Mollisols, whereas one of the major soil orders in the Palghat Gap is mildly acidic Alfisols (Krishnan et al., 1996).

In NEH areas on sedimentary and gneissic rock, strongly acidic Ultisols are associated with moderately acidic Alfisols (Bhattacharyya et al., 2000a; Maji et al., 2000, 2001; Nayak et al., 1996b; Sen et al., 1996, 1999; Singh et al., 1999). In the Andaman and Nicobar Islands on calcareous/micaceous sandstones and lime stones, neutral to slightly alkaline Mollisols are associated with slightly acidic $\mathrm{pH}$ Alfisols (Das et al., 1996).

The soils of the zeolitic Deccan basalt, gneiss/calc-gneiss, sedimentary deposits, lime stones have kaolinite and other hydroxy-interlayered clay minerals in abundance and represent Ultisols, Alfisols and Mollisols, suggesting that the presence of Ca-bearing weatherable minerals in the soil parent materials under forest vegetation have influenced the weathering rate and exerted a decisive influence on the nature of the soil silicate clay minerals and the formation of soils with various soil orders (Pal et al., 1989). It follows from these results that factors and processes of formation and persistence of these three soil orders in adverse HT climate during the Cenozoic time (Idnurm and Schmidt, 1986; Kumar, 1986; Tardy et al., 1991) need a further critique in the light of the existing conceptual models for tropical soil formation.

In either residual (Chesworth, 1973) or haplosoil model of soil formation (Chesworth, 1980) in tropical climate, it was envisaged that with a combination of high temperature and adequate moisture, the HT climate of India provided a weathering environment that should have nullified the effects of parent material composition by resulting kaolinitic and/or oxidic mineral assemblages. The models of Chesworth were based on the hypothesis that (a) the effect of parent rock will be overshadowed and nullified with time; (b) its effect will be evident only in younger or relatively immature soils, and (c) the time is the only independent variable of soil formation or any other processes occurring spontaneously in nature.

In soils of HT climate of India, the dominance of kaolinite indicates that in spite of prolonged weathering for millions of years since the early Tertiary the weathered products of Ca-rich minerals of the parent materials have not reached even the pure kaolinitic mineral stage. The formation of kaolin clay mineral suggests that the formation of Ultisols, Alfisols and Mollisols and their pedogenic threshold at this time supports the supposition that steady state may exist in soils developed over long periods of time spanning not just thousands of years (Smeck et al., 1983; Yaalon, 1971, 1975) but also millions of years. The hypothesis of Chesworth for soil formation in HT climate of India cannot explain the persistence of Ultisols, Alfisols and Mollisols, because of the stability of feldspar, zeolites and other Ca-rich minerals/rock (i.e. limestone, and calc-gneiss) over time was not considered in his model. Therefore, the formation and persistence of these soils provide an example that in an open system such as the soil the existence of a steady state seems a more useful concept than based on equilibrium in a rigorous thermodynamic sense (Bhattacharyya et al., 1999, 2006a,b; Chandran et al., 2005a; Smeck et al., 1983). This contention finds support from the current pedogenetic processes in Ultisols. The OC rich Ultisols have less Al-saturation in surface horizons due to the downward movement of Al as organo-metal complexes or chelates, but have higher base saturation than the sub-surface horizons due to addition of alkaline and alkaline metal cations (Table 2) through litter fall (Nayak et al., 1996a), and there is no desilication and transformation of kaolinite to gibbsite.

In view of contemporary pedogenesis, it is difficult to reconcile that Ultisols (especially of Kerala hitherto considered to be of international reference for laterite) would ever be weathered to reach the Oxisols stage with time frame as envisaged by Smeck et al. (1983) and Lin (2011). The knowledge gained on the role of Ca-rich parent materials in the persistence of soils provides a deductive check on the inductive reasoning on the formation of RF soils in the HT climate.

\section{Importance of pedology of RF soils in their edaphology}

It is often believed that the soils of the tropics are acidic, infertile, and that they do not support a reasonable sustained agricultural production. However, recent research in agricultural production in tropical Asia and Latin America (FAO, 1986) indicate that universal infertility of tropical soils is a myth without scientific documentation (Sanchez and Logan, 1992). It is thus important to highlight with examples on processes such as carbon sequestration potential; acidity, Al toxicity and lime requirement, and adsorption and desorption of major nutrients in tropical Indian acidic RF soils.

\subsection{Carbon sequestration in RF soils of SAT and HT climate}

Out of total stock of soil organic carbon (SOC) of $9.55 \mathrm{Pg}$ in the first $30 \mathrm{~cm}$ depth, Indian soils of the arid (cold arid and hot arid) and semiarid climate have a share of about $40 \%$, the soils of sub-humid, humid and per-humid $47 \%$, and the Ultisols of about $1 \%$ (Bhattacharyya et al., 2000b). Therefore, RF soils of HT climate have considerable amount of OC. Although the RF soils under dry climate contain $<1 \%$ OC, SAT Alfisols under permanent fallow with grass cover could sequester OC up to 1.5\% (Bhattacharyya et al., 2007a), 1\% under horticulture and $1.78 \%$ under forest (Chandran et al., 2009) in the first $30 \mathrm{~cm}$ of the profile. Results from a 7 year study on SAT Alfisols under sorghum-castor bean rotation (Sharma et al., 2005) indicated that conventional tillage with the application of Glyricidia loppings along with $90 \mathrm{~kg} \mathrm{ha}^{-1} \mathrm{~N}$ provided the best soil quality index (SQI). It increased vegetative growth and root 
biomass, which in turn enhanced soil organic matter. The enhanced soil microbial biomass carbon (MBC), made $31 \%$ contribution to SQI; and MBC served as a sensitive indicator of SQI.

In Ultisols, Alfisols and Mollisols of HT climate, $\mathrm{C}$ sequestration is relatively high as indicated by their OC concentration ranges from 1.0 to $5 \%$ (Table 2). These soils are developed under thermic, hyperthermic (Nilgiri Hills in Kerala and Tamil Nadu, Manipur, Meghalaya, Nagaland, Arunachal Pradesh, Assam, Tripura and Mizoram), isohyperthermic (Andaman and Nicobar, Kerala, Tamil Nadu, Madhya Pradesh and Maharashtra) soil temperature regime, and udic (Andaman and Nicobar, Arunachal Pradesh, Manipur, Meghalaya, Assam, Tripura, Nagaland, Mizoram, Nilgiri Hills in Kerala and Tamil Nadu) and ustic (Kerala, Karnataka, Tamil Nadu, Madhya Pradesh and Maharashtra) soil moisture regime (Bhattacharyya et al., 2009).

It is believed that soils in a wet climate under forest have high OC content, sufficient to qualify as Mollisols. The OC addition to Ultisols and Alfisols has been possible as a result of, favourable soil temperature and moisture regime. Several authors reported relationships between clay content, silicate clay type with OC content. It is known that 2:1 expanding clay minerals provide higher surface area for OC accumulation. But a high positive balance of OC in kaolin dominated soils clearly indicates a positive role of this mineral and other hydroxy-interlayered clay minerals because kaolin (like the other hydroxy-interlayered minerals) often shows a relatively high value of CEC $\sim 30 \mathrm{cmol}(\mathrm{p}+) \mathrm{kg}^{-1}$ (Ray et al., 2001) than that of well crystalline kaolinite. Therefore, besides the dominating effect of humid climate in cooler winter months with profuse vegetation, the soil substrate quality in terms of larger surface area is of fundamental importance in OC sequestration in soils (Arrouays et al., 1995; Feller and Beare, 1997; Swift, 2001; Velayutham et al., 2000).

A study on the formation and persistence of acidic and fairly weathered Mollisols and OC rich (>1\%) Alfisols on zeolitic Deccan basalt of humid tropical India (Bhattacharyya et al., 2005, 2006a) in contrast to commonly found alkaline Mollisols in temperate humid climate and Ultisols of HT climate, suggests that Ca-zeolite is an another important factor in OC sequestration. The Ca-zeolites (as soil modifier) are sources of bases to prevent complete transformation of smectite to kaolinite by maintaining relatively high base saturation level in acidic $\mathrm{pH}$ Mollisols and Alfisols.

\subsection{Acidity, Al toxicity and lime requirement in RF soils of HT climates}

Soil acidity is a major constraint to crop production. Contribution of $\mathrm{Al}^{3+}$ ions to exchangeable acidity is significant in the soils of HT climate. Liming is generally recommended for strong to moderately acid soils of tropical India. But in some moderately acidic Alfisols of the Western Ghats, crop response to liming is not observed (Kadrekar, 1979), because of the presence of Ca-zeolites in these soils (Pal et al., 2012a). Aluminium toxicity to plants is a constraint in Oxisols, Ultisols and Dystropepts; and this is also associated with an overall low nutrient reserves (Sanchez and Logan, 1992). Ultisols and Dystropepts of Kerala, Goa, Tamil Nadu, Karnataka and NEH are strongly to moderately acidic, and liming is often recommended to correct soil acidity and improve nutrient availability (ICAR-NAAS, 2010).

Liming is done to bring exchangeable aluminium level in the soil to $<1 \mathrm{mg} \mathrm{kg}^{-1}$ (Sanchez, 1976) for maintaining sustained productivity as a result of general improved nutrient availability (Nayak et al., 1996a, b; Sen et al., 1997a). However, reports on Al toxicity to crops in Indian acidic soils are scarce. The $\mathrm{KCl}$ extractable aluminium is used for liming tropical acidic pH soils (Oates and Kamprath, 1983). It is intriguing that despite equally strongly acidic, Ultisols and Dystropepts of NEH, Ultisols of Kerala, and Alfisols of Goa have varying $\mathrm{KCl}$ exchange acidity. It is less than $1 \mathrm{cmol}\left(\mathrm{p}^{+}\right) \mathrm{kg}^{-1}$ for the Ultisols of Kerala and Meghalaya, and Alfisols of Goa whereas in the Ultisols of Arunachal Pradesh, Assam, Mizoram, Nagaland, Tripura and Dystrochrepts of Manipur, it ranges from 3 to $6 \mathrm{cmol}(\mathrm{p}+) \mathrm{kg}^{-1}$ (Table 2). The lime requirement (LR) of these acidic soils also varies widely. Lime requirement is around $1 \mathrm{t}$ lime ha ${ }^{-1}$ for Ultisols of Meghalaya, and for Dystrochrepts and Ultisols of other states of NEH, it ranges from 4 to $12 \mathrm{t} \mathrm{ha}^{-1}$ (Table 2). Such a low LR $\left(<1 \mathrm{tha}^{-1}\right)$ may be expected for zeolitic soils as soil solution would remain adequately high in soluble Ca-ions from dissolution of Ca-zeolite. But for the gibbsitic-containing Ultisols (Kerala, Meghalaya) and Alfisols ( $\mathrm{Goa}$ ), the reason for low $\mathrm{KCl}$ exchangeable acidity and $\mathrm{LR}$ is not well understood. The role of zeolites and gibbsite in modifying the LR of acid soils needs to be understood to make recommendations for LR on the basis of $\mathrm{KCl}$ exchangeable acidity.

Highly acidic pH Ultisols of Kerala, Karnataka, Tamil Nadu and NEH and moderately acidic Alfisols of Goa, Karnataka and Tamil Nadu have very high $\mathrm{BaCl}_{2}$-TEA extractable acidity in contrast to that they are low to very low $1 \mathrm{~N} \mathrm{KCl}$ exchangeable acidity (Table 2 ). This indicates that $\mathrm{Al}^{3+}$ ions released during the humid tropical weathering are trapped as $\mathrm{Al}(\mathrm{OH})_{2}^{+}$ion in the interlayers of 2:1 minerals to form hydroxyinterlayered minerals (Bhattacharyya et al., 2000a). Both smectites and vermiculites act as sinks for aluminium and thus protect the biota from $\mathrm{Al}$ toxicity. Bhattacharyya et al. (2006b) reported that $\mathrm{BaCl}_{2}-\mathrm{TEA}$ extracts of Ultisols (LAC soils) of Tripura of NEH contained the equivalent stock of $257 \mathrm{Al}^{3+}, 18 \mathrm{Fe}^{3+}$ and $256 \mathrm{H}^{+} \mathrm{kg} \mathrm{ha}^{-1}$ in the first $30 \mathrm{~cm}$ depth. Large quantities of these cations are trapped by vermiculite which otherwise might have created very high acidity as well as Al-toxicity in soils to render them problematic for agricultural use.

\subsection{Nature of minerals in the adsorption and desorption of major nutrients in RF soils of the humid and SAT environments}

\subsubsection{Nitrogen}

As in the case of other soils, RF soils need $\mathrm{N}$ fertilization for agricultural production. One of the forms of mineral $\mathrm{N}$ in soils is fixed $\mathrm{NH}_{4}-\mathrm{N}$. Dalal (1977) reported that selected tropical soils contain large amounts of fixed N. However, the information on fixed N in the soils of HT climate, especially under paddy or lowland rice is scarce, despite the fact that Fe rich soils under such chemical environments do sequester good amount of OC (Sahrawat, 2004a). Iron (Fe) is present in large amounts in RF soils and reducible Fe influence the $\mathrm{NH}_{4}$ production or $\mathrm{N}$ mineralization in submerged soils. In the absence of oxygen, ferric Fe serves as an electron acceptor and affects organic matter oxidation and $\mathrm{NH}_{4}$ production (Sahrawat, 2004b). Similar kind of pedochemical reactions in OC rich RF soils of HT climate under rice in Kerala, Goa, and $\mathrm{NEH}$, is expected to benefit the soils in enriching their fixed $\mathrm{NH}_{4}$ status and minimizing the effect of $\mathrm{N}$ fertilizers.

Information on fixed $\mathrm{NH}_{4}-\mathrm{N}$ is also scarce for $\mathrm{RF}$ soils of the semi-arid tropics (SAT) (Burford and Sahrawat, 1989). Realizing its importance in the N economy of RF soils, Sahrawat (1995) determined the $\mathrm{NH}_{4}-\mathrm{N}$ distribution in a benchmark Alfisol (Patancheru soils at ICRISAT, Patancheru farm, Andhra Pradesh). The amount of fixed $\mathrm{NH}_{4}-\mathrm{N}$ as per cent of total $\mathrm{N}$ varied from 14.0 to $30.8 \%$ and the values generally increased with soil depth. Vermiculites are the only clay minerals to fix $\mathrm{NH}_{4}-\mathrm{N}$ (Pal et al., 2012a). Patancheru soils do contain vermiculites in their silt, coarse and fine clay fractions (Pal et al., 1987, 1993). Vermiculites are the alteration product of biotite and are trioctahedral in nature. During the clay illuviation, the fine clay fractions containing not only the Na-saturated smectite but also vermiculite could translocate downward in the profile. The translocation of clay-vermiculite has enriched the subsoils with vermiculite that explains the observed increasing fixation of $\mathrm{NH}_{4}-\mathrm{N}$ with soil depth (Sahrawat, 1995). It is thus expected that in soils of $\mathrm{HT}$ climate, $\mathrm{NH}_{4}-\mathrm{N}$ is also fixed in discreet vermiculite and also in its hydroxy-interlayered counterpart.

The $\mathrm{NH}_{4}^{+}$ion, also a non-hydrated monovalent cation with almost the same ionic radius as $\mathrm{K}$, is expected to be fixed in the vermiculite interlayers, and thus may not be readily available in soil solution. This way $\mathrm{NH}_{4}^{+}$may be protected from microbial conversion of $\mathrm{NH}_{4}^{+}$to $\mathrm{NO}_{3}^{-}$ because nitrifying bacteria are too large to fit into the interlayer sites, suggesting that the emission of $\mathrm{N}_{2} \mathrm{O}$ from organic (farm yard manure) 
and inorganic $\mathrm{N}$ fertilizers would amount to a small fraction of the total world greenhouse gas emission from RF soils under arable and submerged conditions. Such basic understanding is essential to include fixed $\mathrm{NH}_{4}$ - $\mathrm{N}$ for assessing potentiality of available $\mathrm{N}$ in RF soils especially as $\mathrm{N}_{2} \mathrm{O}$ emission from Indian agricultural soils is a small fraction (about $1 \%$ ) of the total world greenhouse gas emission (Bhatia et al., 2004, 2012).

\subsubsection{Phosphorus}

Moderate to highly acidic RF soils adsorb phosphorus (P) from added phosphate fertilizers, and large doses of $\mathrm{P}$ are required to get desired crop response even when crop requirement of $\mathrm{P}$ is relatively low (Datta, 2013). Soil properties that affect $P$ adsorption include the nature and amount of clay, organic matter, and hydrous oxides of iron and aluminium (Sanyal and DeDatta, 1991).

Clays rich in 1:1 lattice mineral may contribute to P adsorption in highly weathered soils of humid tropical climate, especially at low soil $\mathrm{pH}$, when the activity of iron and aluminium is high. Thus, the Fe and Al-oxy-hydroxides ordinarily present in RF soils have phosphate fixing ability. These complexes occur as fine coatings on surfaces of silicate clay minerals (Haynes, 1983) and these coatings with large specific surface area can adsorb large amounts of added P. This implies that in $\mathrm{P}$ adsorption by $\mathrm{Fe}$ and Al-oxy-hydroxides has a merely secondary role (Ryden and Pratt, 1980). However, these minerals can adsorb negatively charged phosphate ions only when they remain as cations in highly acidic medium. In many Alfisols and Ultisols of India are highly acidic and their $\mathrm{KCl} \mathrm{pH}$ values remain close to equal or greater than water pH (Bhattacharyya et al., 2000a; Chandran et al., 2004, 2005a), indicating the presence of gibbsite and/or poorly crystalline materials (Smith, 1986). A negative/zero/positive $\Delta \mathrm{pH}$ indicates the presence of variable charge minerals such as gibbsite and/or sesquioxides (Bhattacharyya et al., 1994). This indicates that gibbsite and/or sesquioxides showing a positive $\Delta \mathrm{pH}$ could be a better substrate to absorb negatively charged phosphate ions. It is evident from the continuous increment in yield of rice up to $120 \mathrm{~kg} \mathrm{P}_{2} \mathrm{O}_{5} \mathrm{ha}^{-1}$ in gibbsitic soils of Meghalaya (Datta, 2013). This suggests that the highest surface area of 2:1 expanding silicate clay minerals and/or Fe and Al-oxy-hydroxides with no positive sites, have little role in the adsorption of added negatively charged phosphate ions in mild to moderately acidic soils.

Mildly acidic Patancheru soils (SAT Alfisols) contain hydroxyinterlayered vermiculite (HIV) in the silt and coarse clay fractions, and hydroxy-interlayered dioctahedral smectite (HIS) in the coarse and fine clays (Pal et al., 1987). Such hydroxy interlayering is not the contemporary pedogenic process, because in the prevailing mild acidic $\mathrm{pH}$ conditions, the Fe and Al-oxy-hydroxides do not exist as positively charged cations and thus cannot enter the negative environment of the interlayers of vermiculites and smectites (Pal et al., 2012b). Therefore, the formation of HIV and HIS did occur when positively charged hydroxy interlayer materials enter into the interlayer space at a pH 5.0-6.0 (Rich, 1968a). The observed P adsorption is thus related to the formation of $\mathrm{Ca}-\mathrm{P}$ as Patancheru soils like any other SAT Alfisols, contain $1 \% \mathrm{CaCO}_{3}$ (Bhattacharyya et al., 2007a). Calcification is one of the contemporary pedogenetic processes in soils of SAT environments (Pal et al., 2000b).

\subsubsection{Potassium}

9.3.3.1. K adsorption and release in soils of HT climate. Next to nitrogen and phosphorus, potassium ( $\mathrm{K}$ ) is the limiting nutrient element in $\mathrm{RF}$ soils of India, especially in the HT climate areas (Pal et al., 2001). In micaceous soils of HT climate in NEH areas, crops respond to added K up to $80 \mathrm{~kg} \mathrm{~K} \mathrm{ha}^{-1}$ (Datta, 2013). Soils of HT climate are rich in sand size (a)

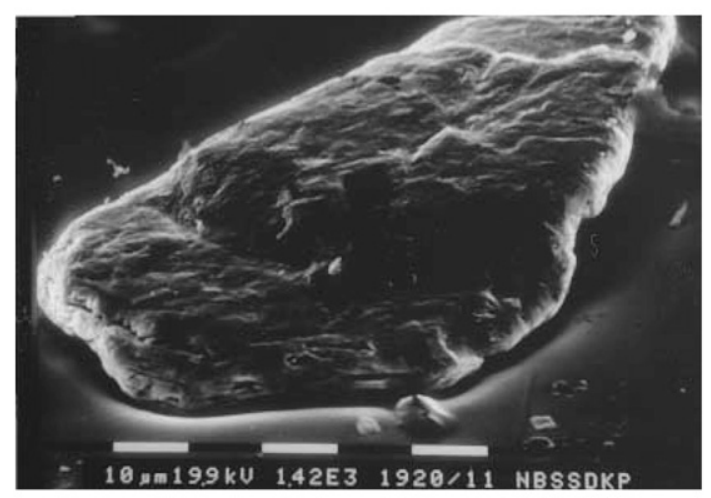

(b)

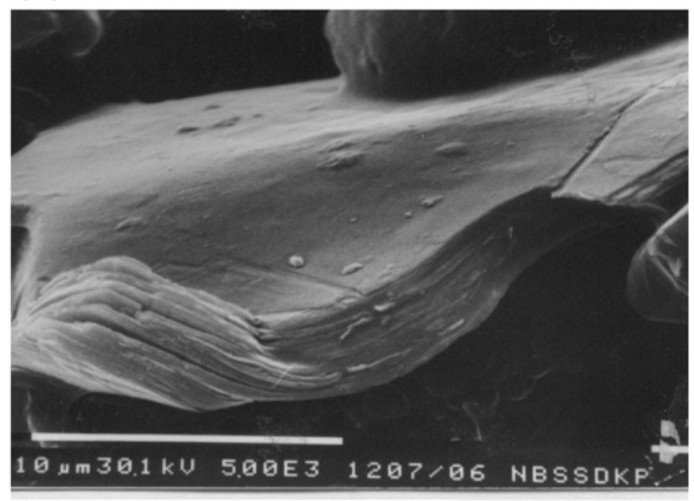

(c)

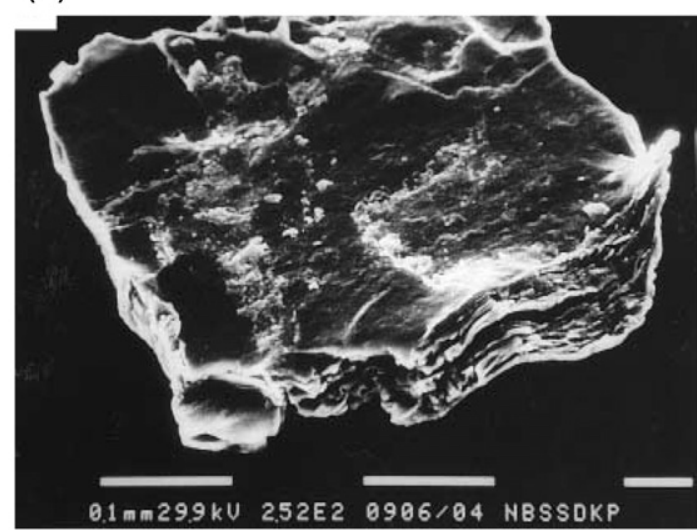

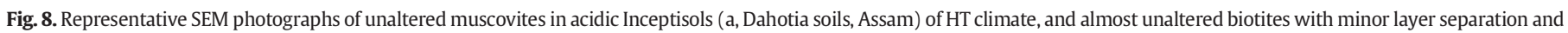
bending of edges in SAT Alfisols (b, Patancheru, Andhra Pradesh and c, Dyavapatna, Karnataka). Adapted from Pal et al. (2000a, 2001). 
Table 3

X-ray intensity ratio of the peak heights of 001/002 basal reflection in the silt and clay fractions.

\begin{tabular}{lllc}
\hline Benchmark Soil/Soil Series & Parent material & \multicolumn{2}{l}{ Size fractions } \\
\cline { 3 - 4 } & & $50-2 \mu \mathrm{m}$ & $<2 \mu \mathrm{m}$ \\
\hline $\begin{array}{l}\text { Dahotia (Assam-HT Climate) } \\
\text { (Typic Haplaquept) }\end{array}$ & Alluvium & 1.47 & 1.10 \\
$\begin{array}{l}\text { Akahugaon (Assam-HT Climate) } \\
\text { (Typic Haplaquept) }\end{array}$ & Alluvium & 1.70 & 1.04 \\
$\begin{array}{l}\text { Patancheru (RF soil-SAT) } \\
\begin{array}{l}\text { Udic Rhodustalf) } \\
\text { Nalgonda (RF soil-SAT) }\end{array}\end{array}$ & Granite-gneiss & 1.77 & 1.80 \\
$\begin{array}{l}\text { (Udic Rhodustalf) } \\
\text { Dyavapatna (RF soil-SAT) }\end{array}$ & Granite-gneiss & 2.00 & 1.87 \\
\hline
\end{tabular}

Adapted from Pal et al. (2012c).

muscovite mica (Fig. 8a). The X-ray intensity ratio of peak heights of 001 and 002 basal reflections of mica in the silt fraction of acidic Alfisols (Chandran et al., 2004), Ultisols (Chandran et al., 2005a) and acidic Inceptisols (Pal et al., 1987) is greater than unity; and that of the clay fraction is close to unity (Table 3 ), indicating that silt fractions contain both muscovite and biotite, and the clay fraction is more muscovitic in character (Pal et al., 2001).

In a repeated batch type experiment with $\mathrm{Ba}-\mathrm{K}$ exchange, $\mathrm{K}$ release from these soils (Dahotia soils of Assam in NEH, Pal and Durge, 1989) was reduced to almost nil after a few extractions, indicating rather slow release of $\mathrm{K}$ from muscovite. Such highly weathered soils fix relatively high amount of added K (Fox, 1982; Pal and Durge, 1989) because of the presence of vermiculite in their silt (20-6 $\mu \mathrm{m}$, and 6-2 $\mu \mathrm{m}$ ) and coarse clay $(2-0.6 \mu \mathrm{m})$ fractions, and low charge vermiculite in their medium $(0.6-0.2 \mu \mathrm{m})$ and fine clay $(<0.2 \mu \mathrm{m})$ fractions (Pal and Durge, 1989). The fine clay of Dahotia soils fixes the most amount of the added $\mathrm{K}$ (Table 4 ).

9.3.3.2. K release and adsorption in SAT soils. It is believed that the predominance of kaolinite followed by illite maintains the low nutrient holding capacity of RF soils (Alfisols) of the southern Peninsular India; and therefore application of balanced fertilizer including $\mathrm{K}$ is generally recommended. However, in many of these soils crops do not respond to K fertilizer application (Ghosh and Biswas, 1978; Rego et al., 1986). The X-ray intensity ratio of peak heights of 001 and 002 basal reflections of mica in the silt and clay fractions of many SAT Alfisols is near 2 (Patancheru, Nalgonda and Dyavapatna soils Table 3), suggesting that these soils contain sufficient biotite.

Paleopedological studies demonstrated that these RF Alfisols of the SAT are relict paleosols of polygenetic nature. As a result of climatic change from tropical humid to semi-arid during the Plio-Pleistocene transition period, the upper layers of the soils of the preceding tropical humid climate were truncated by multiple arid erosional cycles. Erosion exposed the relatively less weathered lower layers wherein considerable amount of unaltered biotite particles remained in the sand and

Table 4

Potassium adsorption by various size fractions of RF Alfisols of the SAT regions (Patancheru and Nalgonda, Andhra Pradesh, India) and acidic Inceptisols (Dahotia of the HT region in Assam, India).

\begin{tabular}{|c|c|c|c|}
\hline \multicolumn{2}{|c|}{ Size fractions } & \multicolumn{2}{|c|}{ Adsorption of added $\mathrm{K}(\mathrm{mg} / 100 \mathrm{~g})$} \\
\hline & Dahotia & Pantancheru & Nalgonda \\
\hline $50-20 \mu \mathrm{m}$ & Nil & 16 & 37 \\
\hline $20-6 \mu \mathrm{m}$ & 0.5 & 36 & 44 \\
\hline $6-2 \mu \mathrm{m}$ & 1.0 & 60 & 62 \\
\hline $2-0.6 \mu \mathrm{m}$ & 26.4 & 128 & 133 \\
\hline $0.6-0.2 \mu \mathrm{m}$ & 31.0 & 90 & 108 \\
\hline$<0.2 \mu \mathrm{m}$ & 50.0 & 90 & 16 \\
\hline
\end{tabular}

Adapted from Pal et al. (1993); Pal and Durge (1989).
Table 5

Potassium release from various size fractions of RF Alfisols (Patancheru and Nalgonda) of southern India.

\begin{tabular}{lcc}
\hline \multirow{2}{*}{ Size fractions } & \multicolumn{2}{c}{ Cumulative K release $(\mathrm{mg} / 100 \mathrm{~g}$ of mica $)$} \\
\cline { 2 - 3 } & Patancheru & Nalgonda \\
\hline $50-20 \mu \mathrm{m}$ & 112 & 450 \\
$20-6 \mu \mathrm{m}$ & 70 & 182 \\
$6-2 \mu \mathrm{m}$ & 88 & 198 \\
$2-0.6 \mu \mathrm{m}$ & 101 & 134 \\
$0.6-0.2 \mu \mathrm{m}$ & 279 & 287 \\
$<0.2 \mu \mathrm{m}$ & 413 & 468 \\
\hline
\end{tabular}

Adapted from Pal et al. (1993).

silt fractions (Fig. 8b, c) (Pal et al., 1989, 1993). Many of the proposed relationships between $\mathrm{K}$ release and mica particle size hitherto obtained either with soil or specimen minerals may not, therefore, be valid in these polygenetic soils (Pal et al., 1993).

The cumulative $\mathrm{K}$ release from different size fractions of two benchmark RF soils (Alfisols) of SAT namely Patancheru and Nalgonda of southern India, indicated a fairly high rate of $\mathrm{K}$ release (Pal et al., 1993). The observed data indicated a contrasting particle size-K release relationship between silts and clays, since $\mathrm{K}$ release increased with the fineness of clay size mica but decreased with the fineness of silt size mica (Table 5). The zones in clay micas are at different stages of expansion, and under such circumstances $\mathrm{K}$ release would occur mainly by edge weathering as is evident from increased $\mathrm{K}$ release with the decrease in mica particle (Pal and Durge, 1989).

Because of the almost unweathered sand and silt biotites (Fig. 8b, c), $\mathrm{K}$ release increased with the increase in particle s silt sized mica. This particular K release trend is normally obtained with specimen micas (Pal, 1985). Thus, quite favourable K release rate from both silt and clay micas explains as to why crop response to fertilizer $\mathrm{K}$ is seldom obtained in many of RF Alfisols under SAT environments.

It is reported that micas, hydrous micas and vermiculites have high adsorption/fixation properties (Brindley, 1966). But mica indeed does not expand on being saturated with divalent cations and unlikely adsorbs added K (Sarma, 1976). In such reactions interlayer charge density of the mineral is of fundamental importance. Kaolinites are of no significance in such a reaction, while vermiculites are converted to mica by layer contraction by K. Smectites would not possess this property as their layer charge is too low and they do not adsorb K selectively (Rich, 1968b) unless the charge density is high like in high charge smectite or low charge vermiculite (Pal and Durge, 1989).

In the absence of considerable amount of vermiculite, the observed $\mathrm{K}$ adsorption by silt and clay fractions of benchmark RF Alfisols of Patancheru and Nalgonda series (Table 4) may be attributed to smectite content because it increases with the decrease in soil size fractions ( $\mathrm{Pal}$ et al., 1993). However, perusal of the K adsorption data (Table 4) indicates that despite sufficient amount of smectite, the finer fractions of clay particularly the fine clay fractions $(<0.2 \mu \mathrm{m})$ does not adsorb K proportionately. The co-existence of both low and high charge smectite is however related to their respective genesis in paleoclimatic environments (Pal et al., 1989). Pal et al. (1989) demonstrated that a part of the well crystallized clay size dioctahedral smectite was the first weathering product of granite-gneiss that survived transformation to kaolinite in a Pre-Pliocene tropical humid climate and is preserved to the present along with kaolinite.

The biotite which somehow survived HT climate weathering, altered to trioctahedral smectite in the silt and coarse clay fractions under the semi-arid climate of the Plio-Pleistocene transition period. The results on the selective $\mathrm{K}$ adsorption by trioctahedral smectite and not by dioctahedral smectite are in accord with those reported earlier with high and low charge smectites respectively (Pal and Durge, 1987, 1989). SAT Alfisols are generally rich in clay, especially fine clays and therefore, it is envisaged that these soils may have less $\mathrm{K}$ fixation problem (Pal et al., 2000a). 


\section{Extent of degradation in RF soils}

A detailed report by ICAR-NAAS (2010) on the degraded and wastelands of India suggests that water erosion is the most widespread form of soil degradation in the Indian sub-continent; and the erosion affects $73.27 \mathrm{~m}$ ha area spreading in all agro-climatic zones. The extent and severity of soil degradation are governed by the intensity of the rainfall, slope of the land, and the types of soil and land use. Soils under HT climate of NEH and southern peninsular areas are most affected by water erosion, and the highest area under this category of degradation is in Nagaland (87\%), followed by Meghalaya (78\%), Arunachal Pradesh (73\%), Assam (66\%), Manipur (53\%), Tripura (38\%), Sikkim (37\%) and Kerala (15\%).

It was assumed that soil erosion $<10 \mathrm{t} \mathrm{ha}^{-1} \mathrm{yr}^{-1}$ (using the empirical Universal Soil Loss Equation, USLE to estimate spatial variations of soil loss factors like R, K, LS, C and P factors) generally does not significantly affect soil productivity; and the soils with loss $<10 \mathrm{t} \mathrm{ha}^{-1} \mathrm{yr}^{-1}$ were not considered degraded (ICAR-NAAS, 2010). Such assumption on soil loss may not be prudent in soils under HT climate, because of the dominance of Ultisols, Alfisols, Mollisols, and Inceptisols with clay enriched B horizons in NEH areas, Kerala, Goa, Maharashtra, Madhya Pradesh, Karnataka and Andaman and Nicobar Islands (Table 1).

The role of the major processes are evident through the addition of $C$ by litter falls and its accumulation as soil organic matter under adequate vegetation and climate, translocation of clay particles (to form clay enriched B horizons) and transformation of 1.4 minerals to kaolin. The rate of soil formation varies from $<0.25 \mathrm{~mm} \mathrm{yr}^{-1}$ in dry and cold environments to $>1.5 \mathrm{~mm} \mathrm{yr}^{-1}$ in humid and warm environments (Kassam et al., 1992). If the rate of $1 \mathrm{~mm} \mathrm{yr}^{-1}$ is taken for top soil formation, then it would amount to $13.3 \mathrm{tha}^{-1}$ when the weight of hectare-furrow slice (15 cm depth) is taken as $2.2 \times 10^{6} \mathrm{~kg}$.

For soils of HT climate, if the rate is taken as $2.0 \mathrm{~mm} \mathrm{yr}^{-1}$ the amount of top soil formation would be around $29 \mathrm{t} \mathrm{ha}^{-1} \mathrm{yr}^{-1}$ (as shown for soils of Tripura in NEH, Bhattacharyya et al., 2007b). This suggests that the rate of soil loss by water erosion from Ultisols, Alfisols, Mollisols and Inceptisols is minimal (Bhattacharyya et al., 2007b). As a result, the formation of mature soils (like Ultisols, Alfisols, Mollisols and clay enriched Inceptisols) on a stable landscape under HT climate is possible. However, in RF soils (mainly Entisols) on higher slopes (ridges, scarps and terraces) under low vegetation with only shrubs and bushes, soil development is greatly hampered by the severe soil loss due to water erosion. Soil loss is also evident in other soils that have less vegetative cover. Besides proper mechanical conservation measures, such soils areas may be used for forestry, horticultural and plantation crops to build resilience in them (Bhattacharyya et al., 1998, 2007b).

Under the SAT environments, the RF soils of Indian states also suffer soil loss due to erosion, and the loss is maximum in Karnataka (49\%) followed by Andhra Pradesh (40\%) and Tamil Nadu (20\%) (ICARNAAS, 2010), considering soil loss $>10 \mathrm{tha}^{-1} \mathrm{yr}^{-1}$ as the threshold for soil degradation. The RF soils of SAT dominantly belong to Alfisols, and the other soil orders are Inceptisols, Entisols and Mollisols (Table 1). Considering the rate of soil formation in dry environments at $<0.25 \mathrm{~mm} \mathrm{yr}^{-1}$ (Kassam et al., 1992), SAT Alfisols would gain soil at least $3.67 \mathrm{tha}^{-1} \mathrm{yr}^{-1}$. However, short-term hydrological studies on small agricultural watershed on Alfisols at the ICRISAT Center, Patancheru, India indicate an average soil loss from SAT Alfisols under traditional system is around $3.84 \mathrm{t} \mathrm{ha}^{-1} \mathrm{yr}^{-1}$ (Pathak et al., 1987). On the other hand, the results from long-term study reported an annual soil loss of $4.62 \mathrm{t} \mathrm{ha}^{-1}$ (Pathak et al., 2013).

The higher soil loss on the SAT Alfisols under traditional management was attributed to crusting, sealing and low structural stability (Pathak et al., 1987, 2013). However, many SAT Alfisols have clay enriched B horizons with substantial amount of smectite silicate clay mineral in the subsoils (Fig. 2b) (Chandran et al., 2009; Pal et al., 1989). Thus, they show moderate shrink-swell properties (coefficient of linear extensibility, COLE > 0.06, Bhattacharyya et al., 2007a), and have reduced saturated hydraulic conductivity in the subsoils (Pathak et al., 2013). Such physical and mineralogical environments in the subsoil restrict vertical movement of water in the soil profile, resulting in greater soil loss from the SAT Alfisols through overland lateral flow of water. Vertical movement of water will be further restricted in SAT Alfisols that have subsoil sodicity due to the formation of pedogenic $\mathrm{CaCO}_{3}$ (Chandran et al., 2011; Pal et al., 2000b, 2013).

To reduce unwarranted soil loss and also to improve the sustainability of the SAT Alfisols, improved system of management developed by the ICRISAT (Pathak et al., 1987) may help. ICRISAT's improved system (improved water management, land development and soil conservation practices combined with appropriate cropping systems, Pathak et al., 1987) minimized soil loss to nearly $1 \mathrm{t} \mathrm{ha}^{-1} \mathrm{yr}^{-1}$ and simultaneously increased crop productivity compared to traditional system. From the above discussion, it is suggested that a threshold value of soil loss by water erosion as sign of degradation, should be based on experimental results rather than assuming an arbitrary value of $>10 \mathrm{t} \mathrm{ha}^{-1} \mathrm{yr}^{-1}$ (ICAR-NAAS, 2010).

Acid soils develop under HT climatic environment with a loss of soil fertility. Indeed, development of acidity in soils is a sign of chemical degradation. While estimating the area degraded by acidity, soils with strong $(\mathrm{pH}<4.5)$ and moderate acidity $(\mathrm{pH} 4.5-5.5)$ only were considered. With this assumption, it is estimated that about $6.98 \mathrm{~m}$ ha area is affected by soil acidity, which is about $9.4 \%$ of the total geographical area of the country (ICAR-NAAS, 2010). Soils of HT climate in the states of Kerala, Goa, Karnataka, Tamil Nadu and NEH areas are strong to moderately acidic Alfisols, Ultisols and Mollisols (Table 2); and their further weathering in HT climate would finally end up in Ultisols with considerable amount of layer silicate minerals (Pal et al., 2012a). Such OC rich acid soils do respond to management interventions and support luxuriant forest vegetation, horticultural, cereal crops, tea, coffee and spices (Sehgal, 1998). Therefore, it would not be prudent to class them as chemically degraded soils.

At present, the extent of degradation (soil loss and soil acidity) of RF soils (especially Ultisols, Alfisols, Mollisols and Inceptisols with clay enriched B horizons) is not at an alarming stage. But they require improved management (IM) practices developed by researchers to upgrade and maintain their nutrient status and make efficient use of soil water to sustain crop productivity at an enhanced level. The IM system package includes improved seeds, NPK fertilizers, micronutrients, FYM and use of gypsum (for sodic soils), use of legumes in the cropping sequence (Bhattacharyya et al., 2007c), lime (Datta, 2013), and improved water management, land development and the implementation of the soil conservation practices for acidic Alfisols, Ultisols and Inceptisols (Datta, 2013) and SAT Alfisols (Pathak et al., 1987, 2009, 2013).

\section{Concluding remarks}

Red ferruginous (RF) soils of tropical environments belong to five taxonomic soil orders (Entisols, Inceptisols, Alfisols, Mollisols and Ultisols), suggesting that tropical RF soils in India have captured a wide soil diversity. The occurrence of Ultisols along with those of acidic Alfisols and Mollisols in both zeolitic and non-zeolitic parent materials in humid tropical climatic environments provides a unique example of tropical soil formation. And this fact was not much appreciated, until the role of zeolites and other base rich parent materials was implicated and confirmed by research conducted in India during the last two decades. Furthermore, these soils support multiple production systems and generally maintain positive organic carbon balance. Although the extent of soil loss by erosion, and acidity in Ultisols, Alfisols, Mollisols and Inceptisols (with clay enriched B horizons) is generally moderate, these soils do require improved nutrient, water and soil water management practices under conservation based agriculture to sustain crop productivity at an enhanced level. This review on the recent developments on the pedology of RF soils of the SAT areas highlights that the Alfisols of SAT areas are relict and polypedogenetic in nature. The 
synthesis of literature attempts to provide insights in several pedological and edaphological aspects of Alfisols, Mollisols and Ultisols mainly of HT climate. The information summarized also helps to understand as to why the formation of Oxisols from Ultisols is an improbable genetic pathway in Indian tropical environment and also elsewhere in the world. Hopefully, the review would enhance our understanding on the formation of tropical soils and their fertility. To sustain crop productivity at an enhanced level, large tracts of lands dominated by RF soils need to be brought under improved soil, water and nutrient management to help meet the food needs of ever increasing Indian population.

\section{Acknowledgements}

We thank several researchers especially those in the National Bureau of Soil Survey and Land Use Planning (NBSS\&LUP) (ICAR), Nagpur, India, whose studies helped us with this review. Useful discussions with Drs. D. C. Nayak, T. K. Sen, P. Chandran, K. M. Nair and T. Bhattacharyya, Principal Scientists of NBSS\&LUP helped improve the quality of this paper. We also appreciate suggestions and comments from the editor and also two anonymous reviewers, which greatly improved the quality of the manuscript.

\section{References}

Aleva, G.J.J., 1994. Laterites: Concepts, Geology, Morphology and Chemistry. In: Creutzberg, D. (Ed.), International Soil Reference and Information Centre (ISRIC), Wageningen, The Netherlands.

Arrouays, D., Vion, I., Klein, J.L., 1995. Spatial analysis and modeling of topsoil carbon storage in temperate forest loamy soils of France. Soil Sci. 159, 191-198.

Balasubramaniam, K.S., Sabale, S.G., 1984. Mineralogy, geochemistry and genesis of certain bauxite profiles from Kutch district, Gujarat. Proceedings of Symposium on Deccan Trap and Bauxite. Special Publication. Geological Survey of India, 14, pp. 225-242.

Beinroth, F.H., 1982. Some highly weathered soils of Puerto Rico. 1. Morphology, formation and classification. Geoderma 27, 1-27.

Bhatia, A., Pathak, H., Aggarwal, P., 2004. Inventory of methane and nitrous oxide emissions from agricultural soils of India and their global warming potential. Curr. Sci. 87, 317-324.

Bhatia, A., Aggarwal, P.K., Jain, N., Pathak, H., 2012. Green house gas emission from ricewheat growing areas in India: spatial analysis and upscaling. Greenh. Gases Sci. Technol. 2, 115-125.

Bhattacharyya, T., Pal, D.K., Deshpande, S.B., 1993. Genesis and transformation of minerals in the formation of red (Alfisols) and black (Inceptisols and Vertisols) soils on Deccan Basalt in the Western Ghats, India. J. Soil Sci. 44, 159-171.

Bhattacharyya, T., Sen, T.K., Singh, R.S., Nayak, D.C., Sehgal, J.L., 1994. Morphology and classification of Ultisols with Kandic horizon in north eastern region. J. Indian Soc. Soil Sci. 42, 301-306.

Bhattacharyya, T., Pal, D.K., Deshpande, S.B., 1997. On kaolinitic and mixed mineralogy classes of shrink-swell soils. Aust. J. Soil Res. 35, 1245-1252.

Bhattacharyya, T., Mukhopadhyay, S., Baruah, U., Chamuah, G.S., 1998. Need for soil study to determine degradation and landscape stability. Curr. Sci. 74, 42-47.

Bhattacharyya, T., Pal, D.K., Srivastava, P., 1999. Role of zeolites in persistence of high altitude ferruginous Alfisols of the Western Ghats, India. Geoderma 90, 263-276.

Bhattacharyya, T., Pal, D.K., Srivastava, P., 2000a. Formation of gibbsite in presence of 2:1 minerals: an example from Ultisols of northeast India. Clay Miner. 35, 827-840.

Bhattacharyya, T., Pal, D.K., Velayutham, M., Chandran, P., Mandal, C., 2000b. Total carbon stock in Indian soils: issues, priorities and management. Land Resource Management for Food and Environmental Security, Soil Conservation Society of India, New Delhi, pp. 1-46.

Bhattacharyya, T., Sarkar, D., Dubey, P.N., Ray, S.K., Gangopadhyay, S.K., Baruah, U., Sehgal, J., Ram Babu, Sarkar, D., Mandal, C., Nagar, A.P., 2004. Soil series of Tripura. NBSS Publication No. 111. NBSS\&LUP, Nagpur (115 pp.).

Bhattacharyya, T., Pal, D.K., Chandran, P., Ray, S.K., 2005. Land-use, clay mineral type and organic carbon content in two Mollisols-Alfisols-Vertisols catenary sequences of tropical India. Clay Res. 24, 105-122.

Bhattacharyya, T., Pal, D.K., Lal, S., Chandran, P., Ray, S.K., 2006a. Formation and persistence of Mollisols on Zeolitic Deccan basalt of humid tropical India. Geoderma 136, 609-620.

Bhattacharyya, T., Pal, D.K., Velayutham, M., Vaidya, P.,2006b. Sequestration of aluminium by vermiculites in LAC soils of Tripura. Abstract, 71st Annual Convention and National Seminar on "Developments of Soil Science" of the Indian Society of Soil Science, Bhubaneswar, Orissa, p. 1.

Bhattacharyya, T., Chandran, P., Ray, S.K., Pal, D.K., Venugopalan, M.V., Mandal, C., Wani, S.P., 2007a. Changes in levels of carbon in soils over years of two important food production zones of India. Curr. Sci. 93, 1854-1862.

Bhattacharyya, T., Babu, Ram, Sarkar, D., Mandal, C., Dhyani, B.L., Nagar, A.P., 2007b. Soil loss and crop productivity model in humid tropical India. Curr. Sci. 93, 1397-1403.
Bhattacharyya, T., Chandran, P., Ray, S.K., Mandal, C., Pal, D.K., Venugopalan, M.V., Durge, S.L., Srivastava, P., Dubey, P.N., Kamble, G.K., Sharma, R.P., Wani, S.P., Rego, T.J., Pathak, P., Ramesh, V., Manna, M.C., Sahrawat, K.L., 2007c. Physical and chemical properties of selected benchmark spots for carbon sequestration studies in semi-arid tropics of India. Global Theme on Agro-ecosystems Report No. 35. Patancheru 502 324, Andhra Pradesh, India: International Crops Research Institute for the Semi-Arid Tropics (ICRISAT), and New Delhi. Indian Council of Agricultural Research (ICAR), India (236 pp.).

Bhattacharyya, T., Sarkar, D., Sehgal, J. L., Velayutham, M., Gajbhiye, K. S., Nagar, A. P., Nimkhedkar, S. S., 2009. Soil Taxonomic Database of India and the States (1:250, 000 scale), NBSSLUP Publ. 143, NBSS\&LUP, Nagpur, India, (266 pp).

Bockheim, J.G., Hartemink, A.E., 2013. Distribution and classification of soils with clayenriched horizons in the USA. Geoderma 209-210, 153-160.

Brindley, G.W., 1966. Ethylene glycol and glycerol complexes of smectites and vermiculites. Clay Miner. 6, 237-259.

Brunner, H., 1970. Pleistozäne Klimaschwankungen im Bereich des Östlichen MysorePlateaus (Stüd Indien). Geologie 19, 72-82.

Buol, S.W., Eswaran, H., 2000. Oxisols. Adv. Agron. 68, 151-195.

Burford, J.R., Sahrawat, K.L., 1989. Nitrogen availability in SAT soils: environment effects on soil processes. Soil fertility and fertility management in semi-arid tropical India. In: Christianson, C.B. (Ed.), Proc. Colloq. held at ICRISAT Centre, Patancheru, India, October 10-11, 1988. International Fertilizer Development Centre, Muscle Shoals, AL, pp. 53-60.

Buurman, P., Van Lagen, B., Velthorst, E.J., 1996. Manual of Soil and Water Analysis. Backhuys Publishers, Leiden.

Chandran, P., Ray, S.K., Bhattacharyya, T., Krishnan, P., Pal, D.K., 2000. Clay minerals in two ferruginous soils of southern India. Clay Res. 19, 77-85.

Chandran, P., Ray, S.K., Bhattacharyya, T., Dubey, P.N., Pal, D.K., Krishnan, P., 2004 Chemical and mineralogical characteristics of ferruginous soils of Goa. Clay Res. 23, 51-64.

Chandran, P., Ray, S.K., Bhattacharyya, T., Srivastava, P., Krishnan, P., Pal, D.K., 2005a Lateritic soils of Kerala, India: their mineralogy, genesis and taxonomy. Aust. J. Soil Res. 43, 839-852.

Chandran, P., Ray, S.K., Bhattacharyya, T., Pal, D.K., 2005b. Chemical and mineralogical properties of ferruginous soils of Andaman and Nicobar Islands. Abstract, 70th Annual Convention and National Seminar on "Developments of Soil Science" of the Indian Society of Soil Science. TNAU, Coimbatore, Tamil Nadu, p. 45.

Chandran, P., Ray, S.K., Bhattacharyya, T., Sen, T.K., Sarkar, D., Pal, D.K., 2006. Rationale for mineralogy class of ferruginous soils of India. Abstract, 15th Annual Convention and National Symposium on "Clay Research in Relation to Agriculture, Environment and Forestry" of the Clay Minerals Society of India. BCKVV, Mohanpur, West Bengal, p. 1.

Chandran, P., Ray, S.K., Durge, S.L., Raja, P., Nimkar, A.M., Bhattacharyya, T., Pal, D.K., 2009 Scope of horticultural land-use system in enhancing carbon sequestration in ferruginous soils of the semi-arid tropics. Curr. Sci. 97, 1039-1046.

Chandran, P., Ray, S. K., Sarkar, D., Bhattacharyya, T., Mandal, C., Pal, D. K., Nagaraju, M.S.S. Ramakrishna, Y.S., Venkateswarlu, B., Chary, G. R. Nimkar, A. M., Raja, P. Maurya, U. K Durge, S. L., Anantwar, S. G., Patil, S. V., Gharami, S., 2011. Soils of Hayatnagar Research Farm of CRIDA (Hyderabad), Rangareddy District, Andhra Pradesh. NBSS Publ. No. 1037, NBSS\&LUP, Nagpur, 174 pp + soil map on 1:5000 scale.

Chesworth, W., 1973. The parent rock effect in the genesis of soil. Geoderma 10, 215-225.

Chesworth, W., 1980. The haplosoil system. Am. J. Sci. 280, 969-985.

Dalal, R.C., 1977. Fixed ammonium and carbon-nitrogen ratios of Trinidad soils. Soil Sci. $124,323-327$.

Das, A. L., Goswami, A., Thampi, C. J., Sarkar, D., Sehgal, J., 1996. Soils of Andaman and Nicobar Islands for optimising land use, NBSS Publ. 61 (Soils of India Series), National Bureau of Soil Survey and Land Use Planning, Nagpur, India, 57 pp +5 sheets of soil map (1:50,000 scale).

Datta, M., 2013. Soils of north-eastern region and their management for rain-fed crops. In: Bhattacharyya, T., Pal, D.K., Sarkar, D., Wani, S.P. (Eds.), Climate Change and Agriculture. Studium Press, New Delhi, pp. 19-50.

Eswaran, H., 1972. Micromorphological indicators of pedogenesis in some tropical soils derived from basalts from Nicaragua. Geoderma 7, 15-31.

Eswaran, H., Sys, C., 1979. Argillic horizon in LAC soils formation and significance to classification. Pédologie 29, 175-190.

Eswaran, H., Kimble, J., Cook, T., Beinroth, F.H., 1992a. Soil diversity in the tropics: implications for agricultural development. In: Lal, R., Sanchez, P.A. (Eds.), Myths and Science of Soils of the Tropics. SSSA Special Publication Number 29. SSSA, Inc. and ACA, Inc., Madison, Wisconsin, USA, pp. 1-16.

Eswaran, H., Krishnan, P., Reddy, R.,S., Reddy, P.S.A., Sarma, V.A.K., 1992b. Application of 'Kandi' concept to soils of India. J. Indian Soc. Soil Sci. 40, 137-142.

FAO (Food and Agriculture Organization of the United Nations), 1986. Yearbook of Agriculture for 1985. FAO, Rome.

Feller, C., Beare, M.H., 1997. Physical control of soil organic matter dynamics in the tropics. Geoderma 79, 69-116.

Fox, R.L., 1982. Some highly weathered soils of Puerto Rico, 2. Chemical properties Geoderma 27, 139-176.

Ghosh, A.B., Biswas, C.R., 1978. Potassium responses and changes in soil potassium status with time. Potassium in Soils and Crops. Potash Research Institute of India, Delhi, pp. 379-390.

Harindranath, C. S., Venugopal, K. R., Raghu Mohan, N. G., Sehgal, J., Velayutham, M. V. 1999. Soils of Goa for optimising land use. NBSS Publ. 74b (Soils of India Series), National Bureau of Soil Survey and Land Use Planning, Nagpur, India, 131 pp +2 sheets of soil map on 1:500,000 scale.

Haynes, R.J., 1983. Effect of lime and phosphate applications on the adsorption of phosphate, sulphate, and molybdate by a spodosol. Soil Sci. 135, 221-226. 
Herbillon, A.J., Frankart, R., Vielvoye, L., 1981. An occurrence of interstratified kaolinitesmectite minerals in a red-black soil toposequence. Clay Miner. 16, 195-201.

Hsu, Pa Ho, 1989. Aluminium hydroxides and oxyhydroxides. In: Dixon, J.B., Weed, S.B. (Eds.), Minerals in Soil Environments. Soil Science Society of America, Madison, WI, pp. 331-378.

ICAR-NAAS (Indian Council of Agricultural Research-National Academy of Agricultura Sciences), 2010. Degraded and Wastelands of India - Status and Spatial Distribution. Indian Council of Agricultural Research and National Academy of Agricultura Sciences. Published by the Indian Council of Agricultural Research, New Delhi, (56 pp.).

Idnurm, M., Schmidt, P.W., 1986. Paleo-magnetic dating of weathered profile. Geol. Surv. India Mem. 120, 79-88.

Jackson, M.L., 1963. Aluminium bonding in soils: a unifying principle in soil science. Proc. Soil Sci. Soc. Am. 27, 1-10

Jackson, M.L., 1964. Chemical composition of soils. In: Bear, F.E. (Ed.), Chemistry of the Soil. Van Norshtand-Reenhold, New York, pp. 71-141.

Jones, R.C., Hundall, W.H., Sakai, W.S., 1982. Some highly weathered soils of Puerto Rico. Mineral. Geoderma 27, 75-137.

Kadrekar, S.B., 1979. Utility of basic slag and liming material in lateritic soils of Konkan. Indian J. Agron. 25, 102-104.

Kassam, A.H., van Velthuizen, G.W., Fischer, G.W., Shah, M.M., 1992. Agro-ecological land resource assessment for agricultural development planning: a case study of Kenya resources data base and land productivity. Land and Water Development Division, Food and Agriculture Organisation of the United Nations and International Institute for Applied System Analysis, Rome.

Kharche, V.K., 1996. Developing soil-site suitability criteria for some tropical plantation crops. (Ph. D thesis) In: P D K V Dr. (Ed.), (Akola, Maharashtra, India).

Kooistra, M.J., 1982. Micromorphological Analysis and Characterization of 70 Benchmark Soils of India. Soil Survey Institute, Wageningen, The Netherlands.

Krishnan, P., Venugopal, K. R., Sehgal, J., 1996. Soil Resources of Kerala for land use planning. NBSS Publ. 48b (Soils of India Series 10), National Bureau of Soil Survey and Land Use Planning, Nagpur, India, 54 pp +2 sheets of soil map on 1:500,000 scale.

Kumar, A., 1986. Palaeo-altitudes and the age of Indian laterites. Palaeogeogr. Palaeoclimatol. Palaeoecol. 53, 231-237.

Lal, S., Deshpande, S.B., Sehgal, J.L., 1994. Soil Series of India. Soils Bulletin No. 40National Bureau of Soil Survey and Land Use Planning (ICAR), Nagpur, India, (684 pp.).

Lin, H., 2011. Three principles of soil change and pedogenesis in time and space. Soil Sci. Soc. Am. J. 75, 2049-2070.

Lowe, D.L., 1986. Controls on the rate of weathering and clay mineral genesis in airfall tephras: a review and New Zealand case study. In: Colman, S.M., Dethier, D.P. (Eds.), Rates of Chemical Weathering of Rocks and Minerals. Academic Press, Orlando, FL, pp. 265-330.

Macedo, J., Bryant, R.B., 1987. Morphology, mineralogy and genesis of a hydro sequence of Oxisols in Brazil. Soil Sci. Soc. Am. J. 51, 690-698.

Maji, A.K., Dubey, P.N., Verma, T.P., Chamuah, G.S., Sehgal, J., Velayutham, M., 2000. Soils of Nagaland: their kinds, distribution, characterisation and interpretations for optimising land use. NBSS Publ., 67b. NBSS\&LUP, Nagpur, (28 pp.)

Maji, A.K., Dubey, P.N., Sen, T.K., Verma, T.P., Marathe, R.A., Chamuah, G.S., Sehgal, J, Velayutham, M., Gajbhiye, K.S., 2001. Soils of Mizoram: their kinds, distribution, characterisation and interpretations for optimising land use. NBSS Publ., 75b. NBSS\&LUP, Nagpur, (28 pp.).

Millot, G., 1970. Geology of Clays. Springer-Verlag, New York.

Mohr, E.C.J., Van Baren, F.A., van Schuylenborgh, J., 1972. Tropical Soil - a Comprehensive Study of Their Genesis. Mouton, The Hague, The Netherlands,

Muggler, C.C., 1998. Polygenetic Oxisols on tertiary surfaces, Minas Gerais, Brazil: soil genesis and landscape development. (PhD thesis) Wageningen Agricultural University, The Netherlands.

Murali, V., Murthy, G.S.R.K., Sarma, V.A.K., 1978. Clay mineral distribution in two toposequences of tropical soils of India. Geoderma 20, 257-269.

Murthy, R.S., Hirekerur, L.R., Deshpande, S.B., Venkat Rao, B.V. (Eds.), 1982. Benchmark Soils of India. National Bureau of Soil Survey and Land Use Planning, Nagpur, India (374 pp.).

Natarajan, A., Reddy, P. S. A., Sehgal, J., Velayutham, M., 1997. Soil Resources of Tamil Nadu for land use planning. NBSS Publ. 46b (Soils of India Series), National Bureau of Soil Survey and Land Use Planning, Nagpur, India, 88 pp +4 sheets of soil map on $1: 500,000$ scale.

Nayak, D.C., Sen, T.K., Chamuah, G.S., Sehgal, J.L., 1996a. Nature of soil acidity in some soils of Manipur. J. Indian Soc. Soil Sci. 44, 209-214

Nayak, D. C., Chamuah, G.S., Maji, A. K., Sehgal, J., Velayutham, M., 1996b. Soils of Arunachal Pradesh for optimising land use. NBSS Publ. 55b (Soils of India Series), National Bureau of Soil Survey and Land Use Planning, Nagpur, India, 54 pp + one sheet soil map (1:500,000 scale)

Oates, K.M., Kamprath, E.J., 1983. Soil acidity and liming: effects of the extracting solution cations and $\mathrm{pH}$ on the removal of aluminium from acid soils. Soil Sci. Soc. Am. J. 47, 686-690.

Pal, D.K., 1985. Potassium release from muscovite and biotite under alkaline conditions. Pedologie (Ghent) 35, 133-146.

Pal, D.K., Deshpande, S.B., 1986. Genesis and transformation of clay minerals of two red soil (Ustalf) pedons of south India. XIII Int. Congr. Soil Sci. Trans., 4, pp. 1471-1472.

Pal, D.K., Deshpande, S.B., 1987. Genesis of clay minerals in a red and black complex soils of southern India. Clay Res. 6, 6-13.

Pal, D.K., Durge, S.L., 1987. Potassium release and fixation reactions in some benchmark Vertisols of India in relation to their mineralogy. Pedologie (Ghent) 37, 103-116.

Pal, D.K., Durge, S.L., 1989. Release and adsorption of potassium in some benchmark alluvial soils of India in relation to their mineralogy. Pedologie (Ghent) 37, 103-116.

Pal, D.K., Roy, B.B., 1978. Characteristics and genesis of some red and lateritic soils occurring in toposequence in eastern part of India. Indian Agric. 22, 9-28.
Pal, D.K., Deshpande, S.B., Durge, S.L., 1987. Weathering of biotite in some alluvial soils of different agro climatic zones. Clay Res. 6, 69-75.

Pal, D.K., Deshpande, S.B., Venugopal, K.R., Kalbande, A.R., 1989. Formation of diand trioctahedral smectite as an evidence for paleoclimatic changes in southern and central Peninsular India. Geoderma 45, 175-184

Pal, D.K., Deshpande, S.B., Durge, S.L., 1993. Potassium release and adsorption reactions in two ferruginous soils (polygenetic) soils of southern India in relation to their mineralogy. Pedologie (Ghent) 43, 403-415.

Pal, D.K., Kalbande, A.R., Deshpande, S.B., Sehgal, J.L., 1994. Evidence of clay illuviation in sodic soils of north-western part of the Indo-Gangetic plains since the Holocene. Soil Sci. 158, 465-473.

Pal, D.K., Dasog, G.S., Vadivelu, S., Ahuja, R.L., Bhattacharyya, T., 2000a. Secondary calcium carbonate in soils of arid and semi-arid regions of India. In: Lal, R., Kimble, J.M., Eswaran, H., Stewart, B.A. (Eds.), Global Climate Change and Pedogenic Carbonates. Lewis Publishers, Boca Raton, Florida, pp. 149-185.

Pal, D.K., Bhattacharyya, T., Deshpande, S.B., Sarma, V.A.K., Velayutham, M., 2000b. Significance of minerals in soil environment of India. NBSS Review Series, 1. NBSS\&LUP, Nagpur, (68 pp.).

Pal, D.K., Srivastava, P., Durge, S.L., Bhattacharyya, T., 2001. Role of weathering of finegrained micas in potassium management of Indian soils. Appl. Clay Sci. 20, 39-52.

Pal, D.K., Sarma, V.A.K., Datta, S.C., 2002. Chemical composition of soils. In: Fundamentals of Soil Science. Indian Society of Soil Science, New Delhi, pp. 243-268.

Pal, D.K., Srivastava, P., Bhattacharyya, T., 2003. Clay illuviation in calcareous soils of the semi-arid part of the Indo-Gangetic Plains, India. Geoderma 115, 177-192.

Pal, D.K., Bhattacharyya, T., Chandran, P., Ray, S.K., Satyavathi, P.L.A., Durge, S.L., Raja, P., Maurya, U.K., 2009. Vertisols (cracking clay soils) in a climosequence of Peninsular India: evidence for Holocene climate changes. Quat. Int. 209, 6-21.

Pal, D.K., Wani, S.P., Sahrawat, K.L., 2012a. Vertisols of tropical Indian environments: pedology and edaphology. Geoderma 189-190, 28-49.

Pal, D.K., Bhattacharyya, T., Sinha, R., Srivastava, P., Dasgupta, A.S., Chandran, P., Ray, S.K., Nimje, A., 2012b. Clay minerals record from Late Quaternary drill cores of the Ganga Plains and their implications for provenance and climate change in the Himalayan Foreland. Palaeogeogr. Palaeoclimatol. Palaeoecol. 356-357, 27-37.

Pal, D.K., Bhattacharyya, T., Chandran, P., Ray, S.K., 2012c. Linking minerals to selected soil properties and climate change: a review. Clay Res. 31, 38-69.

Pal, D.K., Sarkar, D., Bhattacharyya, T., Datta, S.C., Chandran, P., Ray, S.K., 2013. Impact of climate change in soils of semi-arid tropics (SAT). In: Bhattacharyya, T., Pal, D.K., Sarkar, D., Wani, S.P. (Eds.), Climate Change and Agriculture. Studium Press, New Delhi, pp. 113-121.

Pascoe, E.H., 1965. A Manual of the Geology of India and Burma. Manager of Publications, Delhi, (2017 pp.)

Pathak, P., Singh, S., Sudi, R., 1987. Soil and water management alternatives for increased productivity on SAT Alfisols. Soil Conservation and Productivity. Proceedings IV International Conference on Soil Conservation, Maracay-Venezuela, November 3-9, 1985, pp. 533-550

Pathak, P., Sahrawat, K.L., Wani, S.P., Sachan, R.C., Sudi, R., 2009. Opportunities for water harvesting and supplemental irrigation for improving rainfed agriculture in semiarid areas. In: Wani, S.P., Rockström, J., Oweis, T. (Eds.), Rainfed Agriculture: Unlocking the Potential. CABI International, Oxfordshire, U.K., pp. 197-221.

Pathak, P., Sudi, R., Wani, S.P., Sahrawat, K.L., 2013. Hydrological behaviour of Alfisols and Vertisols in the semi-arid zone: implications for soil and water management. Agric. Water Manag. 118, 12-21.

Ray, S.K., Chandran, P., Durge, S.L., 2001. Soil taxonomic rationale: kaolinitic and mixed mineralogy classes of highly weathered ferruginous soils. Abstract, 66th Annual Convention and National Seminar on "Developments in Soil Science" of the Indian Society of Soil Science, Udaipur, Rajasthan, pp. 243-244.

Rebertus, R.A., Buol, S.W., 1985. Intermittency of illuviation in Dystrochrepts and Hapludults from the Piedmont and Blue Ridge province of North Carolina. Geoderma 36, 277-291

Rego, T.J., Sahrawat, K.L., Burford, J.R., 1986. Depletion of soil potassium in an Alfisol under improved rainfed and cereal/legume cropping system in the Indian SAT. Transactions 13th Int. Congr. Soil Sci. 3, 928-929.

Rengasamy, P., Krishna Murthy, G.S.R., Sarma, V.A.K., 1975. Isomorphous substitution of iron for aluminium in some soil kaolinites. Clay Clay Miner. 23, 211-214.

Rengasamy, P., Sarma, V.A.K., Murthy, R.S., Krishna Murthy, G.S.R., 1978. Mineralogy, genesis and classification of ferruginous soils of the eastern Mysore Plateau, India. J. Soil Sci. 29, 431-445.

Rich, C.I., 1968a. Hydroxy-interlayering in expansible layer silicates. Clay Clay Miner. 16, $15-30$.

Rich, C.I., 1968b. Mineralogy of soil potassium. In: Kilmer, et al. (Eds.), The Role of Potassium in Agriculture. American Society of Agronomy, Madison, Wisconsin, pp. 79-108.

Ryden, J.C., Pratt, P.F., 1980. Phosphorus removal from wastewater applied to land. Hilgardia 48, 1-36.

Sahasrabudhe, Y.S., Deshmukh, S.S., 1981. The laterites of the Maharashtra State. In: Laterisation Processes. Proceedings International Seminar. A.A. Balkema, Rotterdam, pp. 209-220.

Sahrawat, K.L., 1995. Fixed ammonium and carbon-nitrogen ratios of some semi-arid tropical Indian soils. Geoderma 68, 219-224.

Sahrawat, K.L., 2004a. Organic matter accumulation in submerged soils. Adv. Agron. 81, 169-201.

Sahrawat, K.L., 2004b. Ammonium production in submerged soils and sediments: the role of reducible iron. Commun. Soil Sci. Plant Anal. 35, 399-411.

Sanchez, P.A., 1976. Properties and Management of Soils in the Tropics. John Wiley and Sons, New York

Sanchez, P.A., Logan, T.J., 1992. Myths and science about the chemistry and fertility of soils in the tropics. In: Lal, R., Sanchez, P.A. (Eds.), Myths and Science of Soils of the Tropics. 
SSSA Special Publication Number 29. SSSA, Inc and ACA, Inc, Madison, Wisconsin, USA, pp. 35-46.

Sanyal, S.K., DeDatta, S.K., 1991. Chemistry of phosphorus transformations in soil. In: Stewart, B.A. (Ed.), Advances in Soil Science. Springer-Verlag, New York, pp. 1-120.

Sarma, V.A.K., 1976. Mineralogy of soil potassium. Bull. Indian Soc. Soil Sci. 10, 66-77.

Schwertmann, U., Herbillon, A.J., 1992. Some aspects of fertility associated with the mineralogy of highly weathered tropical soils. In: Lal, R., Sanchez, P.A. (Eds.), Myths and Science of Soils of the Tropics. SSSA Special Publication Number 29. SSSA, Inc and ACA, Inc, Madison, Wisconsin, USA, pp. 47-59.

Sehgal, J.L., 1998. Red and lateritic soils: an overview. In: Sehgal, J., Blum, W.E., Gajbhiye, K.S. (Eds.), Red and Lateritic Soils. Managing Red and Lateritic Soils for Sustainable Agriculture, 1. Oxford and IBH Publishing Co. Pvt. Ltd., New Delhi, pp. 3-10.

Sen, T.K., Chamuah, G.S., Sehgal, J.L., 1994. Occurrence and characteristics of some Kandi soils of Manipur. J. Indian Soc. Soil Sci. 42, 297-300.

Sen, T. K., Chamuah, G. S., Maji, A. K., Sehgal, J., 1996. Soils of Manipur for optimising land use. NBSS Publ. 56b (Soils of India Series), National Bureau of Soil Survey and Land Use Planning, Nagpur, India, 52p +1 sheet map.

Sen, T.K., Dubey, P.N., Chamuah, G.S., Sehgal, J.L., 1997a. Landscape-soil relationship on a transect in central Assam. J. Indian Soc. Soil Sci. 45, 136-141.

Sen, T.K., Nayak, D.C., Singh, R.S., Dubey, P.N., Maji, A.K., Chamuah, G.S., Sehgal, J.L., 1997b. Pedology and edaphology of benchmark acid soils of north-eastern India. J. Indian Soc. Soil Sci. 45, 782-790.

Sen, T.K., Nayak, D.C., Dubey, P.N., Chamuah, G.S., Sehgal, J.L., 1997c. Chemical and electrochemical characterization of some acid soils of Assam. J. Indian Soc. Soil Sci. 45, 245-249.

Sen, T. K., Chamuah, G. S., Sehgal, J., Velayutham, M., 1999. Soils of Assam for optimising land use. NBSS Publ. 66b (Soils of India Series), National Bureau of Soil Survey and Land Use Planning, Nagpur, India, 51 pp +2 sheets map.

Sharma, K.L., Mandal, U.C., Srinivas, K., Vittal, K.P.R., Mandal, B., Grace, J.K., Ramesh, V., 2005. Long-term soil management effects on crop yields and soil quality in a dry land Alfisol. Soil Tillage Res. 83, 246-259.

Shiva Prasad, C. R., Reddy, P. S. A., Sehgal, J., Velayutham, M., 1998. Soils of Karnataka for optimising land use. NBSS Publ. 47b (Soils of India Series), National Bureau of Soil Survey and Land Use Planning, Nagpur, India, 111 pp +4 sheets of soil map on 1 : 500,000 scale.

Singh, R. S., Maji, A.K., Sehgal, J., Velayutham, M., 1999. Soils of Meghalaya for optimising land use, NBSS Publ. 52b (Soils of India Series). National Bureau of Soil Survey and Land Use Planning, Nagpur, India, p.29 + 1 sheet soil map (1:500,000scale).

Smeck, N.E., Runge, E.C.A., Mackintosh, E.E., 1983. Dynamics and genetic modeling of soil system. In: Wilding, L.P., Smeck, N.E., Hall, G.F. (Eds.), Pedogenesis and Soil Taxonomy: 1. Concepts and Interactions. Elsevier, New York, pp. 51-81.
Smith, G.D., 1986. The Guy Smith Interviews: Rationale for Concept in Soil Taxonomy. SMSS Technical Monograph, 11. SMSS, SCS, USDA, USA.

Srivastava, P., Chandran, P., Ray, S.K., Bhattacharyya, T., 2001. Evidence of chemical degradation in tropical ferruginous soils of southern India. Clay Res. 20, 31-41.

Srivastava, P., Bhattacharyya, T., Pal, D.K., 2002. Significance of the formation of calcium carbonate minerals in the pedogenesis and management of cracking clay soils (Vertisols) of India. Clay Clay Miner. 50, 111-126.

Srivastava, P., Rajak, M., Sinha, R., Pal, D.K., Bhattacharyya, T., 2010. A high resolution micromorphological record of the Late Quaternary Paleosols from Ganga-Yamuna Interfluve: stratigraphic and paleoclimatic implications. Quat. Int. 227, 127-142.

Subramanian, K.S., Mani, G., 1981. Genetic and geomorphic aspects of laterites on high and low landforms in parts of Tamil Nadu, India. Laterisation Processes. Proceedings International Seminar. A. A. Balkema, Rotterdam, pp. 236-245.

Survey Staff, Soil, 1990. Keys to soil taxonomy, SMSS Technical MonographFourth edition, 19, (Blacksburg, Virginia, USA)

Swift, R.S., 2001. Sequestration of carbon by soil. Soil Sci. 166, 858-871.

Tait, J.M., Violante, A., Violante, P., 1983. Co-precipitation of gibbsite and bayerite with nordstrandite. Clay Miner. 18, 95-97.

Tardy, Y., Kobilsek, B., Paquet, H., 1991. Mineralogical composition and geographical distribution of African and Brazilian periatlantic laterites. The influence of continental drift and tropical paleoclimates during the last 150 million years and implications for India and Australia. J. Afr. Earth Sci. 12, 283-285.

Van Olphen, H., 1966. An Introduction of Clay Colloid Chemistry. Interscience, New York.

T.Varghese, T., G.Byju, G., 1993. Laterite SoilsTechnical Monograph No.1. State Committee on Science, Technology and Environment. Government of Kerala, Kerala, India.

Velayutham, M., Pal, D.K., Bhattacharyya, T., 2000. Organic carbon stock in soils of India In: Lal, R., Kimble, J.M., Stewart, B.A. (Eds.), Global Climate Change and Tropical Ecosystems. Lewis Publishers, Boca Raton, Fl, pp. 71-96.

Venugopal, K.R., 1997. Types of cutans in some ferruginous soils of Bangalore plateau and their relation with soil development. J. Indian Soc. Soil Sci. 46, 641-646.

Venugopal, K.R., Deshpande, S.B., Kalbande, A.R., Sehgal, J.L., 1991. Textural pedofeatures (clay coatings) in a ferruginous soil from Bangalore plateau. Clay Res. 10, 30-35.

Yaalon, D.H., 1971. Soil forming processes in time and space. In: Yaalon, D.H. (Ed.), Paleopedology. Israel University Press, Jerusalem, pp. 29-39.

Yaalon, D.H., 1975. Conceptual models in pedogenesis. Can soil forming functions be solved? Geoderma 14, 189-205.

Yerima, B.P.K., Calhoun, F.G., Senkayi, A.L., Dixon, J.B., 1985. Occurrence of interstratified kaolinite-smectite in E1 Salvador Vertisols. Soil Sci. Soc. Am. J. 49, 462-466. 